\title{
Correlation of upper Miocene-Pliocene Lake Pannon deposits across the Drava Basin, Croatia and Hungary
}

\author{
Krisztina Sebe ${ }^{1}$, Marijan Kovačić ${ }^{2}$, Imre Magyar ${ }^{3,4}$, Krešimir Krizmanić ${ }^{5}$, Marko Špelić6, \\ Dijana Bigunac ${ }^{7}$, Mária Sütő-Szentai ${ }^{8}$, Ádám Kovács ${ }^{9}$, Andrea Szuromi-Korecz ${ }^{10}$, Koraljka Bakrač $^{6}$, \\ Valentina Hajek-Tadesse ${ }^{6}$, Tamara Troskot-Čorbić ${ }^{5}$ and Orsolya Sztanó ${ }^{9}$
}

1 University of Pécs, Department of Geology and Meteorology, 7624 Pécs, Ifjúság ú. 6, Hungary; (sebe@gamma.ttk.pte.hu)

2 University of Zagreb, Faculty of Science, Department of Geology, 10000 Zagreb, Horvatovac 95, Croatia; (mkovacic@geol.pmf.unizg.hr)

${ }^{3}$ MOL Hungarian Oil and Gas Plc., 1117 Budapest, Október huszonharmadika utca 18., Hungary; (immagyar@mol.hu)

${ }^{4}$ MTA-MTM-ELTE Research Group for Paleontology, Budapest, Hungary

5 INA -Oil Company, Plc., Exploration \& Production, Exploration \& Upstream portfolio development, Lovinčićeva 4, 10000 Zagreb, Croatia; (kresimir.krizmanic@ina.hr; tamara.troskot-corbic@ina.hr)

${ }^{6}$ Croatian Geological Survey, Department of Geology, 10000 Zagreb, Sachsova 2, Croatia; (mspelic@hgi-cgs.hr; kbakrac@hgi-cgs.hr; tadesse@hgi-cgs.hr)

7 INA -Oil Company, Plc., Exploration \& Production, Field Development, V. Holjevca 10, Zagreb, Croatia; (dijana.bigunac@ina.hr)

87300 Komló, Május 1 utca 7., Hungary; (szentai.maria@gmail.com)

${ }^{9}$ Eötvös Loránd University, Department of Geology, 1117 Budapest, Pázmány Péter sétány 1/c; (konformista@caesar.elte.hu, sztano@caesar.elte.hu)

10 MOL Group E\&P Laboratory, 1039 Budapest, Szent István út 14., Hungary; (kaszuro@mol.hu)

doi: $10.4154 / g c .2020 .12$

Article history:

Manuscript received April 27, 2020

Revised manuscript accepted August 24, 2020

Available online October 26, 2020

\begin{abstract}
Upper Miocene to Pliocene (Pannonian) sediments of the Pannonian Basin System accumulated in the brackish Lake Pannon and the fluvial feeder systems, between 11.6-2.6 Ma. Their stratigraphic subdivision has been problematic for a long time due to the laterally prograding architecture of the basin fill and the historically independently evolving stratigraphic schemes of the neighbouring countries. We correlated the lithostratigraphic units of the Lake Pannon deposits between Hungary and Croatia in the Drava Basin, using lithological, sedimentological and palaeontological data from boreholes and outcrops, and seismic correlation. The Croatica and Medvedski breg formations in Croatia correspond to the Endröd Fm. in Hungary, comprising shallow to deep water, open lacustrine, calcareous to argillaceous marls. The Andraševec fm. in Croatia corresponds to the Szolnok and Algyő Fms. in Hungary, consisting of sandstones and siltstones of turbidite systems and of clay marls deposited on the shelf-break slope. The Nova Gradiška $\mathrm{fm}$. in Croatia is an equivalent of the Újfalu Fm. in Hungary, built up of a variety of lithologies, including sand, silt, clay and huminitic clay, deposited in deltaic environments. The Pluska fm. in Croatia corresponds to the Zagyva Fm. in Hungary, consisting of variegated clays, silts, sands and lignites, deposited in alluvial and fluvial environments. Coarse-grained (sand, gravel) basal layers are assigned to the Kálla and Békés Fms. and the Sveti Matej member of the Croatica fm. Coarse-grained intercalations within the deep-water marls belong to the Dorozsma Member of the Endröd Fm. in Hungary, and to the Bačun member of the Medvedski breg fm. in Croatia. Sediment transport and lateral accretion of the shelf edge in the Drava Basin took place from the N, NW, and W, to the S, SE, and E, respectively. According to the biostratigraphic and chronostratigraphic analyses, the oldest shelf-break slopes in the Mura Basin are more than $8 \mathrm{Ma}$ old, whereas the youngest ones in the southeasternmost part of the Drava Basin may be Pliocene in age (younger than $5.3 \mathrm{Ma}$ ). Thus, the $180 \mathrm{~km}$ long and at least $700 \mathrm{~m}$ deep Drava Basin was transformed into a fluvial plain during the last 3.5 million years of the Miocene.
\end{abstract}

Keywords: stratigraphy, correlation, upper Miocene, Pannonian, Drava Basin
OTT \& RADIVOJEVIĆ, 2010; SZTANÓ et al., 2016), but considerable further work is needed to obtain a stratigraphic system applicable to the entire Pannonian Basin System.

In the past decades there have been several efforts aimed at correlating the Miocene sediments of Croatia and Hungary (SAFTIĆ et al., 2003; HEĆIMOVIĆ et al., 2010; MALVIĆ \& CVETKOVIĆ, 2013). The need for this is well demonstrated by MALVIĆ \& CVETKOVIĆ (2013), who called attention to the fact that the otherwise lithologically similar upper Miocene formations appear in the stratigraphic charts as time-transgressive units in Hungary but as units with synchronous boundaries in Croatia. In the framework of the recent Hungarian-Croatian bilateral project „Stratigraphy and correlation of Upper Miocene - Pliocene sediments along the Croatian-Hungarian border", we aimed to correlate the lithostratigraphic scheme of Lake Pannon deposits between Hungary and Croatia in the Drava Basin, a deep subschemes has been achieved in some parts of the basin (e.g. PIG- 
basin in the SW part of the Pannonian Basin System. The fact that the Drava Basin covers a significant proportion of the distribution area of Lake Pannon deposits in Croatia and that several upper Miocene key sections are located in this region adds special importance to the area. Here we present the correlated scheme, the definitions of the stratigraphic units harmonised between the two countries and provide field and borehole examples of the typical appearance of the units. Using seismic correlation and biostratigraphic dating from organic-walled microplankton and molluscs, we offer temporal limits to the deposition of the given units.

\section{GEOLOGICAL SETTING}

The Drava Basin (Fig. 1) formed as a result of early - middle Miocene extension (PRELOGOVIĆ et al., 1998). Above the PalaeoMesozoic basement the basin is filled by nearly $7 \mathrm{~km}$ of Cenozoic sediments (HORVÁTH et al., 2006). In most of the basin and its surroundings the syn-rift succession began in the Eggenburgian or Ottnangian, with terrestrial, fluvial and lacustrine clastics in the lower Miocene and continued with marine deposits in the middle Miocene, both intercalated with volcanics, mostly pyroclastics (HÁMOR, 1970; CHIKÁN, 1991; LUČIĆ et al., 2001; SAFTIĆ et al., 2003; NAGYMAROSY \& HÁMOR, 2012; MALVIĆ \& CVETKOVIĆ, 2013; PAVELIĆ \& KOVAČIĆ, 2018). In the area of the northwestern Drava Basin and in the Mura Basin, the oldest Cenozoic rocks are of Oligocene age and marine sedimentation persisted during the early and middle Miocene. Upper Miocene - Quaternary deposits of the Drava Basin attain a thickness of more than $5 \mathrm{~km}$ (Fig. 1). They accumulated in the brackish Lake Pannon, the related marshes, and in the Pliocene to modern fluvial system following the lake.

Upper Miocene sediments crop out in the mountains bordering the Drava Basin: in Kalnik, Bilogora, Papuk and Krndija in North Croatia on the southern and in the Mecsek Mts. on the northern side (Fig. 1). These mountains represent basement highs and in contrast with continuous sedimentation in the basin, they emerged from Lake Pannon during one or more time intervals in the late Miocene, thus their succession contains sedimentary gaps below, within and above the Lake Pannon deposits (KLEB, 1973; KOVAČIĆ \& GRIZELJ, 2006; KOVAČIĆ et al., 2011; SEBE et al., 2013; SZTANÓ et al., 2015). No upper Miocene outcrops are known in the Villány Hills in Hungary. However, remnants of most probably Lake Pannon sediments preserved in the shallow subsurface in intramountain valleys and elevated karstic cavities (RAKUSZ \& STRAUSZ, 1953; DEZSÖ et al., 2007) suggest that this area was flooded as well for at least some time during the late Miocene.

In the marginal areas surrounding the Drava Basin, sedimentation across the Sarmatian-Pannonian boundary was continuous in the deepest part of small sub-basins, while basement highs underwent moderate uplift and denudation as a result of the socalled "post-Sarmatian inversion event" (SAFTIĆ et al., 2003; HORVÁTH et al., 2006; TOMLJENOVIĆ \& CSONTOS, 2001). Within the Drava Basin itself, the existence of Sarmatian sediments has not been proven with fauna yet, only in the NW in the Mura-Zala basins (KÖRÖSSY, 1989; HORVÁTH et al., 2018). Lake Pannon deposits of the study area accumulated during the post-rift phase of basin evolution (PAVELIĆ, 2001; HORVÁTH et al., 2006; BALÁZS et al., 2016). After this subsidence-dominated interval, basin inversion started in the latest Miocene, coevally with the still ongoing lacustrine deposition, and is still active today (TOMLJENOVIĆ \& CSONTOS, 2001; CSONTOS et al., 2002; KONRÁD \& SEBE, 2010; VAN GELDER et al., 2015).

\section{METHODS}

The lithology, sedimentology and fossils of the target deposits were investigated in the field and in cores in both countries. In order to identify and correlate lithostratigraphic and biostratigraphic units over the entire Drava Basin, a $181 \mathrm{~km}$ long composite seismic section was constructed parallel to the NW-SE trend-

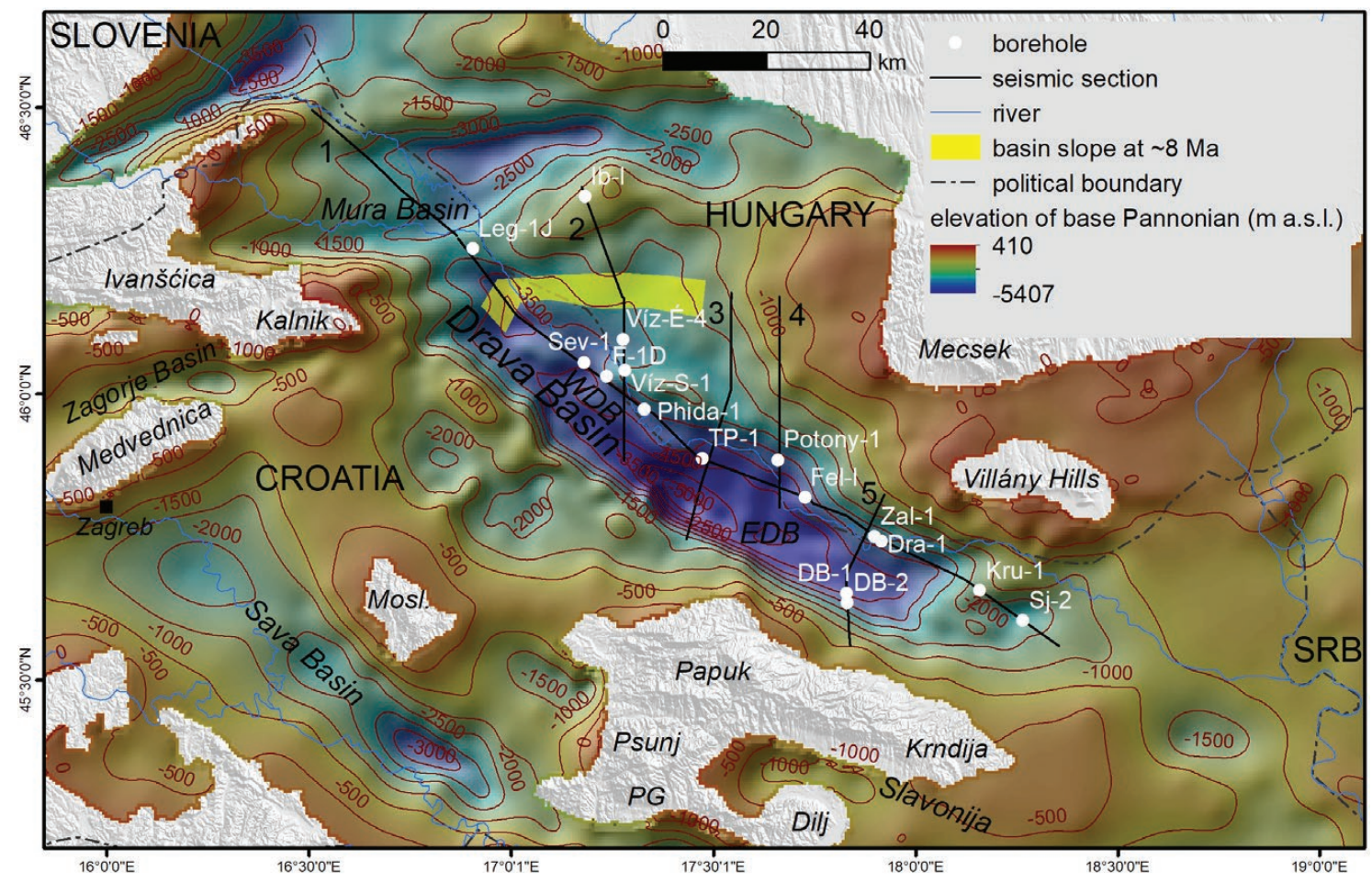

Figure 1. The Drava Basin and its surroundings, with the depth of upper Miocene - Pliocene lacustrine and fluvial sediments. Base Pannonian surface from HORVÁTH et al. (2012). EDB: Eastern Drava Basin; Mosl.: Moslavačka gora; PG: Požeška gora; SRB: Republic of Serbia; WDB: Western Drava Basin. 


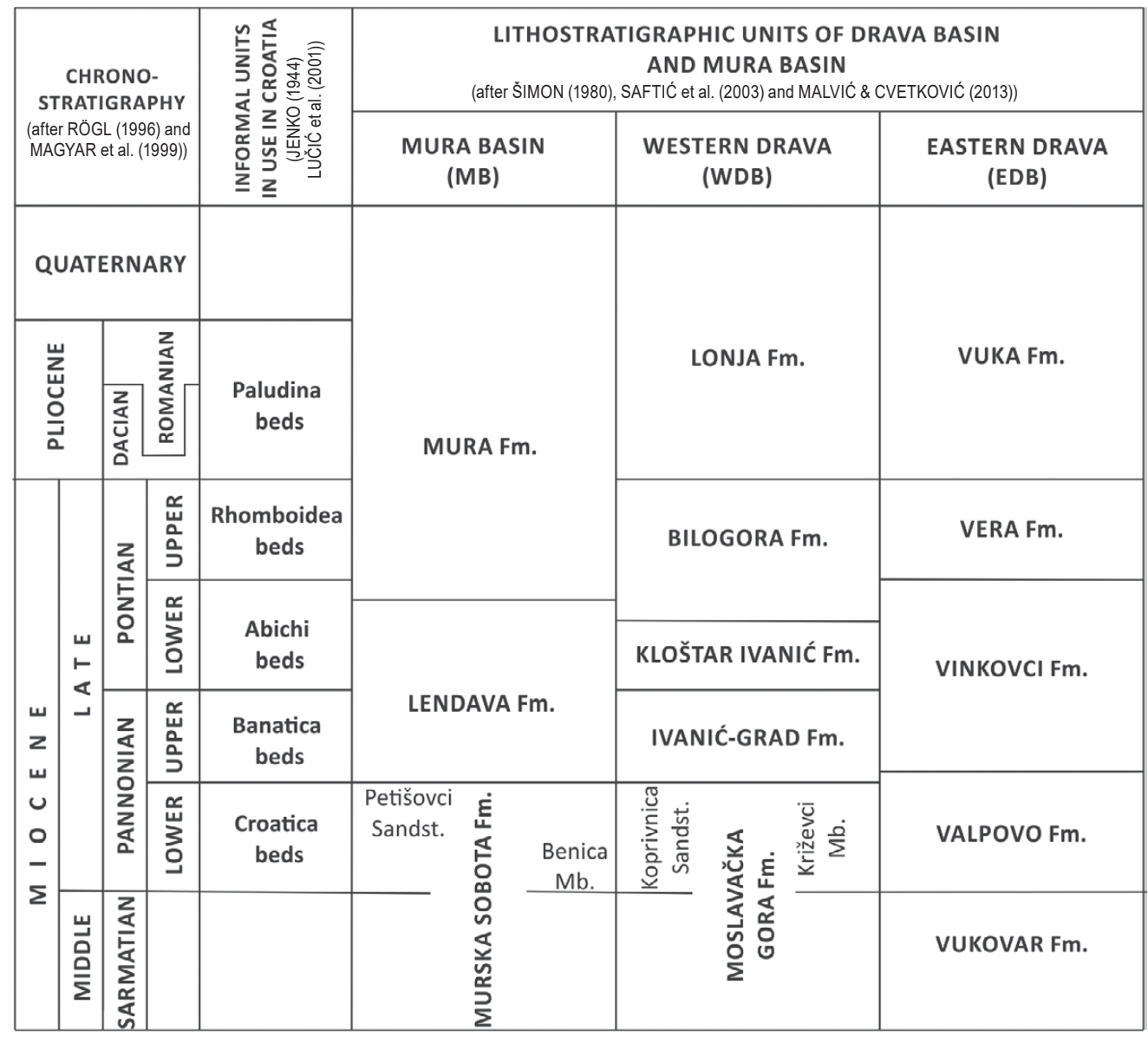

Figure 2. Informal upper Miocene and Pliocene units and lithostratigraphic schemes used for subsurface rocks in the Eastern and Western Drava Basin and in the Mura Basin in Croatia. The concept behind these schemes does not distinguish between bio- and lithostratigraphy and geochronology, therefore it is recommended that they are abandoned.

ing axis of the basin (Fig. 1). This section connects the key wells Legrad (Leg)-1J, Severovci (Sev)-1, Ferdinandovac-1Duboka (F-1D), Péterhida (Phida)-1, Terezino Polje (TP)-1, Felsőszentmárton (Fel)-I, Zaláta (Zal)-1, Dravica (Dra)-1, Krunoslavlje (Kru)-2 and Sječe (Sj)-2, and crosses the Drava river and the Croatian-Hungarian state boundary several times. In addition to this master profile (Fig. 7), four N-S directed crosslines with lengths of 55, 49, 41 and $31 \mathrm{~km}$, respectively, were also compiled (Figs. 1, 8). Key wells Iharosberény (Ih)-I, Vízvár-Észak (Víz-É)-4, VízvárS (Víz-S)-1, Potony-1, and Donja Bukovica (DB)-1 and -2 were connected into the network through these sections. Lithological and biostratigraphic data from the key wells were obtained from well logs and well reports, and these were projected into the seismic network. Time/depth functions for well to seismic tie were taken from the databases of MOL and INA. Additional scattered biostratigraphic data from larger distances were correlated to this seismic network via seismic correlation.

\section{LITHOSTRATIGRAPHIC SCHEMES IN CROATIA AND HUNGARY}

In Croatia three main lithostratigraphic schemes are in use today for upper Miocene deposits of the northern and eastern part of the country.

Earlier studies divided the succession into the 'Croatica', 'Banatica', 'Abichi' and 'Rhomboidea beds', while Pliocene deposits were described as belonging to the 'Paludina beds' (CROATIAN GEOLOGICAL SURVEY, 2009; PIKIJA, 2009; BASCH, 2009) Fig. 2. This division, introduced originally by JENKO
(1944), was primarily based on the superposition of leading mollusc taxa, where the 'Croatica' and 'Banatica beds' were traditionally attributed to the "Lower and Upper Pannonian", while the 'Abichi' and 'Rhomboidea beds' represented the "Lower and Upper Pontian", respectively. This division did not take into account that the spatial and temporal distribution of molluscs is highly dependent on changes of the depositional environment (MAGYAR \& GEARY, 2012). Furthermore, it has since been shown that the Pontian stage, originally defined in the Euxinian (Black Sea) basin, was erroneously correlated into the Pannonian Basin System (e.g. MANDIC et al., 2015). Nevertheless, this scheme is still in use in Croatia, especially in petroleum exploration wells.

The two other systems are more lithology-based. They have been invented for the entire Neogene succession, separately for subsurface and surface sediments. An older system introduced by ŠIMON $(1966,1980)$ and updated later by VELIĆ $(2007)$ is used for subsurface sediments and is based on well and seismic data (Fig. 2). In this system the lithostratigraphic units still have the chronostratigraphic meaning as well, they were defined as equivalents of (sub)stages, neglecting the time-transgressive character of the units. In addition, for historical reasons different names exist for concurrent units in different parts of the basins. This system has long been used in the Drava Basin, with separate lithostratigraphic schemes for the western (WDB) and the eastern (EDB) parts of the basin (ŠIMON, 1966, 1980) (Fig. 2). Due to the aforementioned weaknesses of the first division, a second system has been created in the past thirty years during surveying related to the construction of the Geological Map of the Republic 
of Croatia. New lithostratigraphic units in this system are defined and named according to the International Stratigraphic Guide (MURPHY \& SALVADOR, 1999). The names of these units represent the recommendation of the National Committee for Stratigraphy and are used on recently published geological maps of the Republic of Croatia (map sheets for the Slavonia area: FILJAK et al., 2016a, 2016b; HALAMIĆ et al., 2019). The unification of lithostratigraphic units for the territory of Croatia is currently in progress. Within this process, the names of certain Pannonian lithostratigraphic units described from other parts of Croatia have been adopted to the Drava Basin based on the similar lithology and related depositional setting.

For upper Miocene and Pliocene sediments exposed at the surface, the scheme contains six lithostratigraphic units of formation rank, described in detail below (KOVAČIĆ, 2004; FILJAK et al., 2016a, 2016b; KOVAČIĆ \& PAVELIĆ, 2017; HALAMIĆ et al., 2019) (Fig. 3). In addition, locally derived clastic sediments are classified into different units in different parts of the stratigraphic column. The surface distribution of these formations was outlined by mapping in the Hrvatsko zagorje region and the Medvednica Mts. in NW Croatia, and along the northern margin of the Sava Basin in the Požeška gora Mts. and Dilj gora Mts. in the eastern Croatian region of Slavonia. Geological mapping of the mentioned deposits has not yet been carried out in the Krndija, Papuk and Bilogora Mts. However, as a result of terrain prospecting and recording of detailed geological sections, all the above formations have been identified in these areas (KOVAČIĆ, 2004; KOVAČIĆ \& PAVELIĆ, 2017).

Similarly to Croatia, various stratigraphic schemes developed for individual basins and also for basin margins used to exist in Hungary as well. The standardisation of the system began with the work of JUHÁSZ (1994), who proposed a general, genetically based scheme for all sedimentary basins of Hungary. This became widely accepted and led to significant harmonisation, but basin sediments were still treated separately from those cropping out at the present margins (JUHÁSZ, 1998; KORPÁSNÉ HÓDI, 1998). The past two decades have brought progress in recognizing that except for the oldest formations (Békés, Endrőd and Kálla Fms.) indicating transgression of the lake (SZTANÓ et al., 2010), all other deposits uniformly reflect the infilling process. Therefore a basin-wide correlation of deep, open-water mudstones, turbidite systems, shelf slope mudstones and deltaic to fluvial successions can easily be carried out (e.g. SZTANÓ et al., 2013a, 2013b, 2016; CSILLAG \& SZTANÓ, 2015a, b), regardless of their present topographic position, i.e. buried in deep basin interiors or exposed along margins of the present hills. The formations, both with their litho- and biofacies, follow the evolution of the depositional environments, governed by the long-term normal regression interrupted by minor flooding events or local variations in sediment input. Official formation descriptions accepted by the Stratigraphic Commission of Hungary were published in CSÁSZÁR (1997).

\subsection{Lithostratigraphic units}

Our investigations of both surface and subsurface sediments and their fossil content showed that formation boundaries are timetransgressive over the entire Drava Basin and its surroundings, and do not coincide with the boundaries of either dinocyst or mollusc biozones. Consequently, in our opinion a correlated lithostratigraphic scheme for the upper Miocene - Pliocene lacustrine to fluvial succession should be based on the lithological and sedimentological - and corresponding seismic - characteristics of the deposits. Here we present the proposed lithostratigraphic scheme correlated between Croatia and Hungary (Fig. 3) and the short description of the units.

\subsubsection{Kálla Formation}

Sand, gravelly sand and gravel, typically limonitic, often with abundant molds and imprints of littoral molluscs (Fig. 4) (KLEB, 1973; SZTANÓ et al., 2010; SEBE et al., 2015). It occurs around

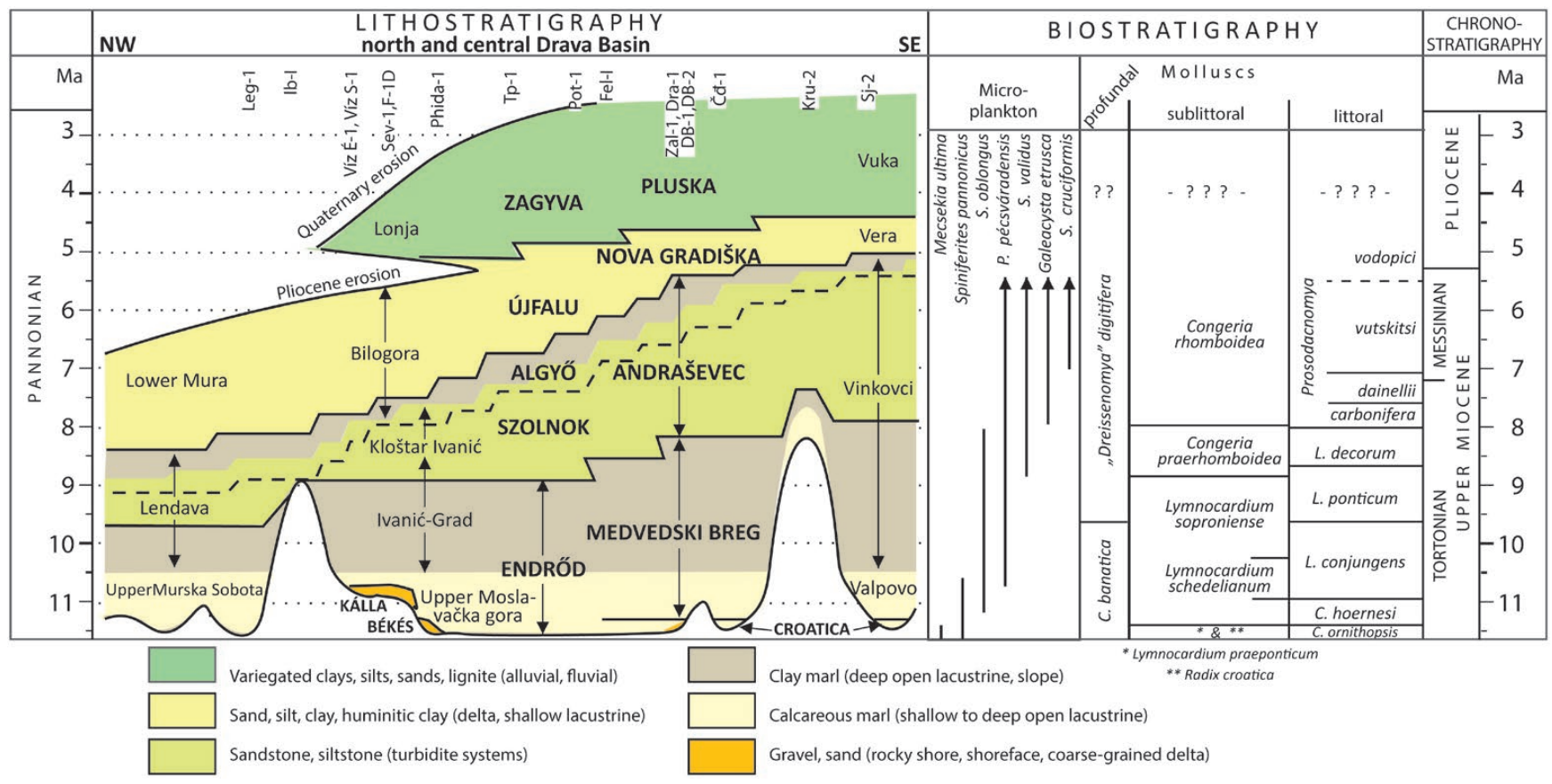

Figure 3. Correlation of the upper Miocene - Pliocene lithostratigraphic units in Croatia and Hungary. Preferred formation names are capitalized, abandoned or local names are in plain format. Age limits of the formations come from biostratigraphy discussed below. Note that the chart follows the axial sediment transport routes, either in deep basin centres or above sublacustrine highs. Marginal areas, which contain more locally-derived clastics and several unconformities, cannot be illustrated in the same figure. 

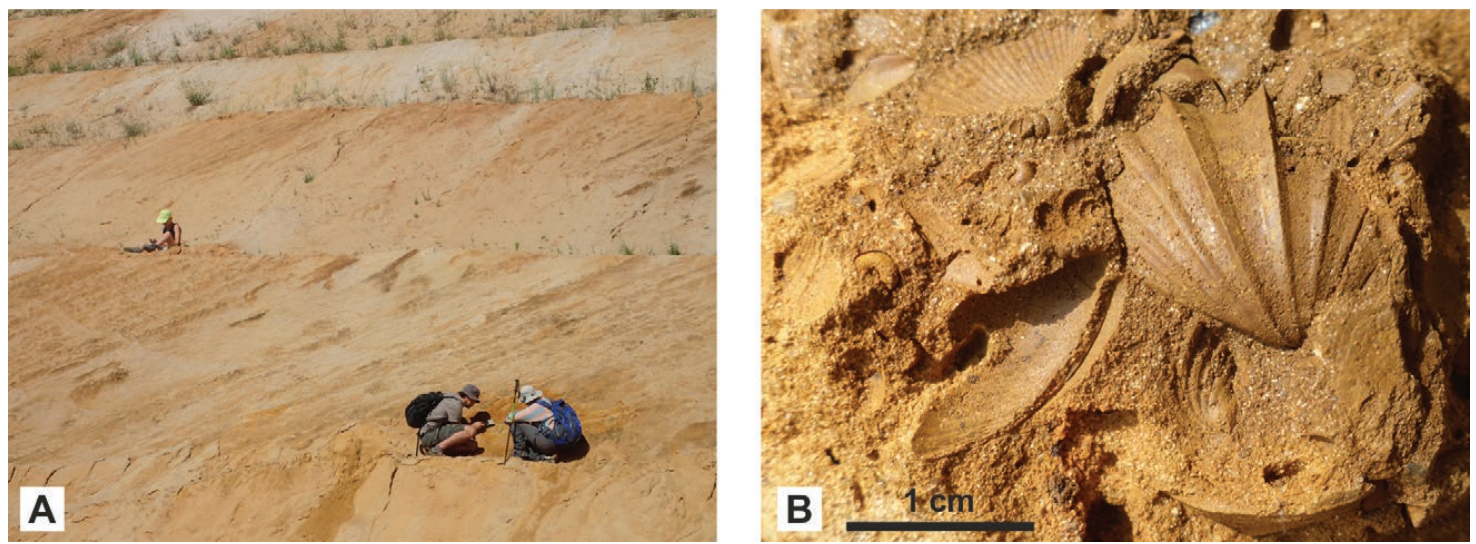

Figure 4. Kálla Formation. A) Tectonically tilted coarse, gravelly sands in the Pécs-Danitzpuszta sand pit; B) limonitic sand with mollusc molds and imprints (Lymnocardium in the centre), Cserdi, W Mecsek Mts.

the basement highs that emerged as islands from the lake. Consequently, it is more abundant along the margins of the Drava Basin. Its material was derived from local sources, from the denudation of the immediate background, and accumulated on the shoreface or on small locally fed deltas. Its thickness ranges from a few metres to a few tens of metres. Being sourced from older rocks, it sometimes contains vertebrate and subordinately invertebrate fossils redeposited from lower - middle Miocene formations or even from Mesozoic rocks (KLEB, 1973; SEBE et al., 2015). In most places it is a transgressive deposit at the base of the Lake Pannon succession, unconformably overlying older rocks, thus its age depends on the time of flooding. At some locations around the Mecsek Mts., where sediment input into the lake was high, it overlies offshore calcareous marls and prinches out, quickly away from the mountains. On palaeohighs flooded at a later stage it interfingers with, or it is overlain by the Újfalu Formation (e.g. BUDAI et al., 2019). The mollusc fauna of the formation contains littoral forms of dreissenids, cardiids, and prosobranch snails, but the actual species composition always depends on the age of the given occurrence (KLEB, 1973; SEBE et al., 2015). The best exposures in the Mecsek are the sand pits of Pécs-Danitzpuszta (with Congeria pancici, C. ungulacaprae, C. partschi, Lymnocardium schedelianum; SEBE et al., 2015), Pécsvárad and Himesháza (with Congeria balatonica, L. dumicici, L. cf. proximum, „Protoplagiodacna” sp., Phyllocardium planum; BUDAI et al., 2019), and Cserdi (with Congeria triangularis, Lymnocardium ferrugineum, L. pelzelni, L. schmidti, L. szaboi, Prosodacnomya dainellii). For the location of sites ment-

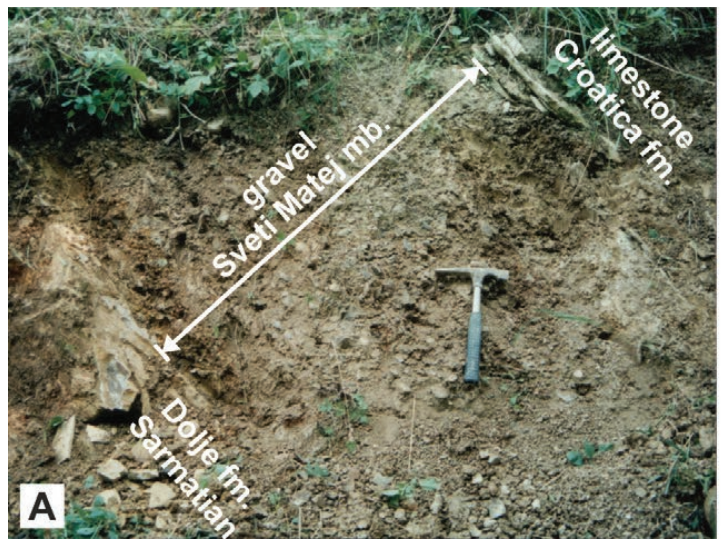
ioned in the text, please refer to Supplement 1.

\subsubsection{Békés Conglomerate Formation, Sveti Matej member of Croatica formation}

Coarse clastics - conglomerates and breccias - occur in the region in two main forms at the base of the calcareous marls (Fig. 5). The sediment is similar in both cases: gravel material is of local origin, while sorting and rounding is variable, depending on the transport and reworking processes and - in the case of the Békés Conglomerate - on water depth, i.e. below or above wave base.

The Sveti Matej member of the Croatica formation is composed of unfossiliferous gravel deposited unconformably over pre-Pannonian rocks in a fluvial environment. It is maximum a few metres thick and is overlain by the thin-bedded limestones of the Croatica fm. (Fig. 5A). It is only known in the Medvednica Mts. As a fluvial sediment, it represents temporary emergence of the area. Terrestrial deposits predating lacustrine flooding in Hungary are classified into the Ösi Variegated Clay Fm., though this unit has not yet been recorded in the Mecsek-Drava area.

The Békés Conglomerate (Fig. 5B) comprises gravels reworked by lacustrine wave action and is conformably overlain by the calcareous marls of the Endröd Fm. Typical grain size is below $10 \mathrm{~cm}$, but the largest clasts can exceed $1 \mathrm{~m}$. Matrix material is either missing or is identical to the overlying marls. The unit is typically unfossiliferous, its thickness ranges from 1-2 $\mathrm{m}$ to $\sim 20 \mathrm{~m}$. The wave-reworked gravels indicate the flooding of drylands, therefore the unit occurs at locations where open lacustrine sediments overlie older rocks unconformably: along the margins and in the southern foreland of the Mecsek Mts. above uplifted basement highs. The best outcrops are in the Monyoród and Versend quarries.

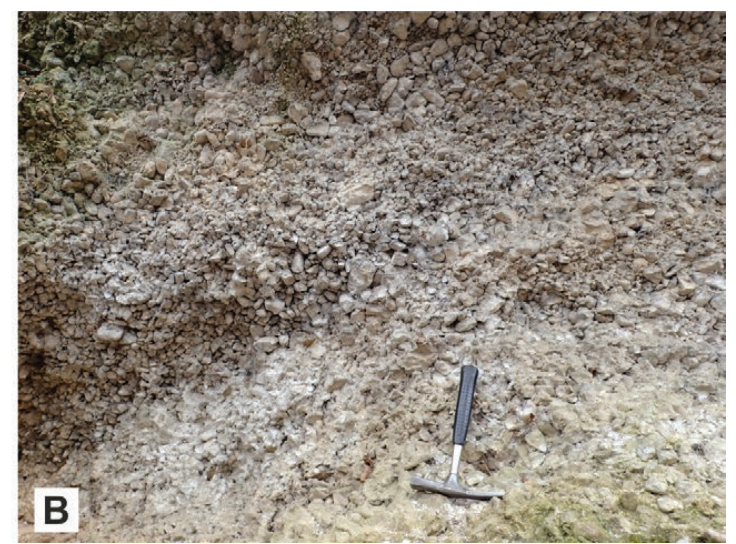

Figure 5. Conglomerates overlying the pre-Pannonian sediments or the basement. A) Gravels of the Sveti Matej member in erosional contact with underlying laminated marls of Sarmatian Dolje formation (Sveti Matej, Medvednica Mts.) B) Békés Conglomerate in the southern foreland of the Mecsek Mts. (Monyoród quarry). 

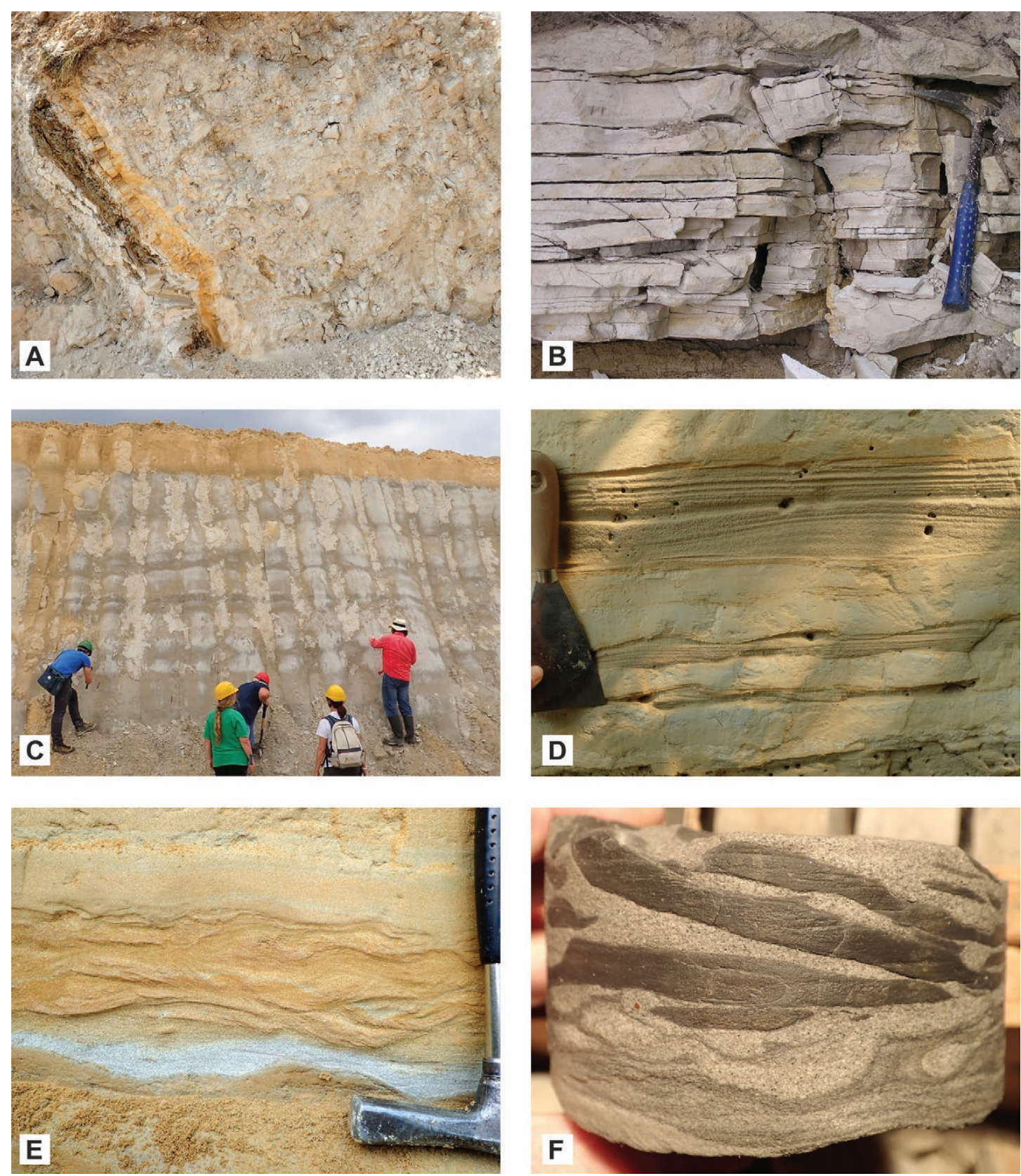

Figure 6. A-C: Endröd Fm./Croatica and Medvedski breg fms. A) Thin-bedded limestones and calcareous marls with clay interbeds in the lower part of the unit (Pécs-Danitzpuszta sand pit, Mecsek Mts.; image width $2 \mathrm{~m}$ ); B) Thin-bedded limestones of the Croatica fm. (Našice quarry, Krndija Mts.); C) Massive calcareous marls in the upper part of Medvedski breg fm. (Našice quarry). D-F: Andraševec fm./Szolnok and Algyő Fms. D) Thin- to medium-bedded graded, laminated turbidites alternate with siltstones at Mirti/Hruševec; E) A graded, structureless to planar and cross-laminated turbidite bed at the lower part of Petnja outcrop; F) Sandstone with imbricated rip-up mud clasts (well TP-1, 2564-2565 m)

\subsubsection{Endrőd Formation, Croatica and Medvedski breg formations}

The carbonate-dominated unit at the bottom of the Lake Pannon succession is treated as one formation in Hungary and as two in Croatia. White and grey, thin-bedded limestones and calcareous marls compose the lower part of the unit, followed by light greyish, thick-bedded to massive calcareous marls, topped by clay marls and silty marls (Fig. 6 A-C). At locations close to basement highs, thin $(<1 \mathrm{~m}$ thick) clastic intercalations (marl, clay, sand and gravel) occur in the lower part of the calcareous marls. Its thickness ranges from a few tens of metres in marginal areas to 50-200 $\mathrm{m}$ in the centre of the Drava Basin (Fig. 7, e.g. well Potony-1). In Hungary the calcareous marl (with $>\sim 70 \%$ carbonate content) at the lower part of the Endröd Fm. is separated as the Tótkomlós Member in the Great Hungarian Plain and as the Belezna Mb. to the west of the Danube. It can be white near basement highs or black in the deep basin interiors (MAGYAR et al., 2004) and contains sufficient amounts of TOC to be a source rock (BADICS \& VETÖ, 2012). The upper part comprising clay marls is distinguished as the Nagykörü Mb. in the Great Hungarian Plain and as the Nagylengyel Mb. in the west (JUHÁSZ, 1998), and it occurs mostly in deep basins. The Endröd Fm. corresponds to the Croatica and Medvedski breg fms. in Croatia, which, based on their lithological composition and stratigraphic position, are further an equivalent of the upper part of the Moslavačka gora Fm. (Križevci Mb.) and the lower part of the Ivanić-Grad Fm. (Lipovac Mb.) in the WDB and the Valpovo Fm. and of the lower part of the Vinkovci Fm. (Laslovo Mb.) in the EDB (Fig. 2) (eg. MALVIĆ \& CVETKOVIĆ, 2013). The unit is conformably over- 
lain by the Szolnok/Andraševec Fm. in the deep basin interiors or by the Algyö/Andraševec Fms. on sublacustrine basement highs.

The formation contains an impoverished sublittoral-profundal mollusc fauna with usually thin-shelled forms, such as Congeria banatica, "Dreissenomya" digitifera, "Pontalmyra" otiophora, various Paradacna species, and deep-water-adapted pulmonate molluscs, such as planorbids (Gyraulus) and lymnaeids (e.g. Velutinopsis, Undulotheca, Valenciennius), as well as a rich ostracod assemblage (JUHÁSZ \& MAGYAR, 1992; KOVAČIĆ, 2004; VASILIEV et al., 2007; Magyar in SEBE et al., 2015). Littoral fossils occur in redeposited interbeds. A diverse thermophilous macroflora was recovered in the Mecsek Mts. in the uppermost part of the formation (HABLY \& SEBE, 2016). The general trend of the unit from carbonate-dominated to clay/ silt-dominated rocks has been attributed primarily to the increasing amount of clastic input into the lake transported by the distal Alpine-Carpathian feeder system approaching the area from the $\mathrm{N}$ and NW. The lower boundary of the formation coincides with the Sarmatian/Pannonian boundary in basins with continuous sedimentation across the middle/late Miocene boundary, while it becomes increasingly unconformable and thus younger away from the basin centres. The youngest biozone identified in the formation within the Drava Basin is the Spiniferites validus dinoflagellate zone ( $<9$ Ma; BAKRAČ et al., 2012 and Fig. 7).

The type localities in Croatia are the Kostanjek and Vrapče sections (Croatica fm.) and the Medvedski breg section (M. b. $\mathrm{fm}$.) in the NW part of the Sava Basin, on the slopes of the Medvednica Mts. (KOVAČIĆ et al., 2016, 2017a; KOVAČIĆ \& PAVELIĆ, 2017). At present the most representative surface occurrences are the Našice quarry on the northern slopes of the Krndija Mts. (KOVAČIĆ et al., 2017a) and the Pécs-Danitzpuszta sand pit in the Mecsek Mts. (SEBE et al., 2019).

\section{Croatica formation}

The lower, well-bedded, hard, carbonate-rich, 20-50 m thick part of the Endröd Fm. occurring in the vicinity of basement highs is distinguished as the Croatica fm. in Croatia. Most commonly it rests conformably over sublittoral Sarmatian deposits, rarely over alluvial sediments which unconformably overlie different basement rocks (Fig 5A). The unit is identified by its $1-10 \mathrm{~cm}$ thick, white calcareous marl or limestone layers (Fig. 6B). Based on their lithological features, thin-layered limestones of the Croatica $\mathrm{fm}$. in the marginal parts of the basin are clearly different from the overlying massive marls of the Medvedski breg fm., while these differences are not clearly expressed in the deeper parts of the basin, where the calcareous marls or limestones conformably overlying Sarmatian deposits are massive, dark grey, and represent source rocks (TROSKOT-ČORBIĆ et al., 2009). The Croatica $\mathrm{fm}$. is the equivalent of the upper part of the Moslavačka gora Fm. (Križevci Mb.) in the WDB and of the Valpovo Fm. in the EDB. It is not equivalent to the Tótkomlós Member within the Endröd Fm., but can be correlated only with its lowermost part. Laterally and upwards it gradually passes into the marls of the Medvedski breg fm. It is widely distributed in the marginal parts of depressions in the southern part of the Pannonian Basin System.

The first description of this unit under the name „Pre-Pontian formation" (GORJANOVIĆ-KRAMBERGER, 1890) already drew attention to its peculiar mollusc fauna, consisting of pulmonate snails (e.g. Radix croatica, Gyraulus praeponticus, G. dubius) and small cardiids (e.g. "Lymnocardium" praeponticum).
The ostracod assemblage contains brackish species (e.g. Herpetocyprella auriculata), while the calcareous nannoplankton association is rich in the endemic species Isolithus semenenko and I. pavelici (ĆORIĆ in KOVAČIĆ et al., 2015, 2017a). The palynological samples contain no dinoflagellates but they are rich in the prasinophyte alga Mecsekia ultima (BAKRAČ, 2005). Freshwater algae representing Sigmopollis spp. have also been identified in this formation (KOVAČIĆ et al., 2015), as well as plant remains (aquatic grasses).

The depositional environment of this unit is usually interpreted as a stressed, low-salinity, shallow-water, littoral-sublittoral setting (VRSALJKO, 1999; KOVAČIĆ et al., 2017a). While marl intercalations are inferred to indicate water-level oscillations that temporarily created deeper water, the sediments of the Croatica $\mathrm{fm}$. are interpreted to reflect lowstand deposition as a consequence of regression at the end of the Sarmatian (PAVELIC et al., 2003). The arguments in favour of the shallow, littoral-sublittoral environment include the abundance of pulmonate snails (Planorbidae and Lymnaeidae), which are mostly known today as shallow-water or paludal dwellers, the lack of dinoflagellate cysts, the presence of prasinophyte algae and rooted aquatic vegetation (e.g. VRSALJKO, 1999; VASILIEV et al., 2007). The overall position of the Croatica fm., lying unconformably above alluvial sediments of the Sveti Matej mb. or different pre-Miocene basement rocks, or conformably overlying shallow-water Sarmatian deposits (VRSALJKO, 1999; KOVAČIĆ et al., 2015), also suggests a relatively shallow water origin.

The typical fauna and algal flora of the Croatica fm., however, can often be observed in lithologically different sediments, always representing the earliest Pannonian. In fact, this special fossil assemblage is apparently present in much of the Pannonian Basin System, in places where the Sarmatian/Pannonian boundary is characterized by continuous sedimentation. It indicates a specific environment, which was obviously widespread in the earliest Pannonian, but did not last very long, only a few hundred thousand years at most. Therefore, this assemblage can be used as a biostratigraphic marker, upon which the „Lymnocardium” praeponticum Zone (KORPÁS-HÓDI, 1987), the Radix croatica - Lymnocardium plicataeformis - Gyraulus praeponticus Cenozone (VRSALJKO, 1999), the Mecsekia ultima Zone (SÜTÖSZENTAI, 1982), and the Mecsekia ultima - Spiniferites bentorii pannonicus Zone (BAKRAČ et al., 2012) were established. The Mecsekia ultima and "Lymnocardium" praeponticum zones have also been reported from deep-water, clay-silt deposits (e.g. SZTANÓ et al., 2005; SÜTÖ-SZENTAI \& SZEGÖ, 2008). Generally, the families of Lymnaeidae and Planorbidae are dominated by littoral and sublittoral taxa indeed, but in Lake Pannon some of their representatives conquered the deep-water environment (JUHÁSZ \& MAGYAR, 1992; GEARY et al., 2000). Even within the Drava Basin, such species of Gyraulus, Velutinopsis and Valenciennius occur in core samples from the bottom of several hundred metre high shelf-break slopes (Fig. 13), indicating a very deep habitat for these animals. Thus, the original habitat of this earliest Pannonian peculiar fossil assemblage remains a puzzle.

\section{Dorozsma Marl Member of the Endröd Formation, Bačun member of the Medvedski breg formation}

In the vicinity of basement highs, the offshore calcareous marls and marls contain clastic intercalations (gravel, sand, silt) originating from the erosion of the emergent blocks. These are classified under the name Bačun mb. within the Croatica and Medvedski breg fms. in Croatia and as the Dorozsma Mb. within the 

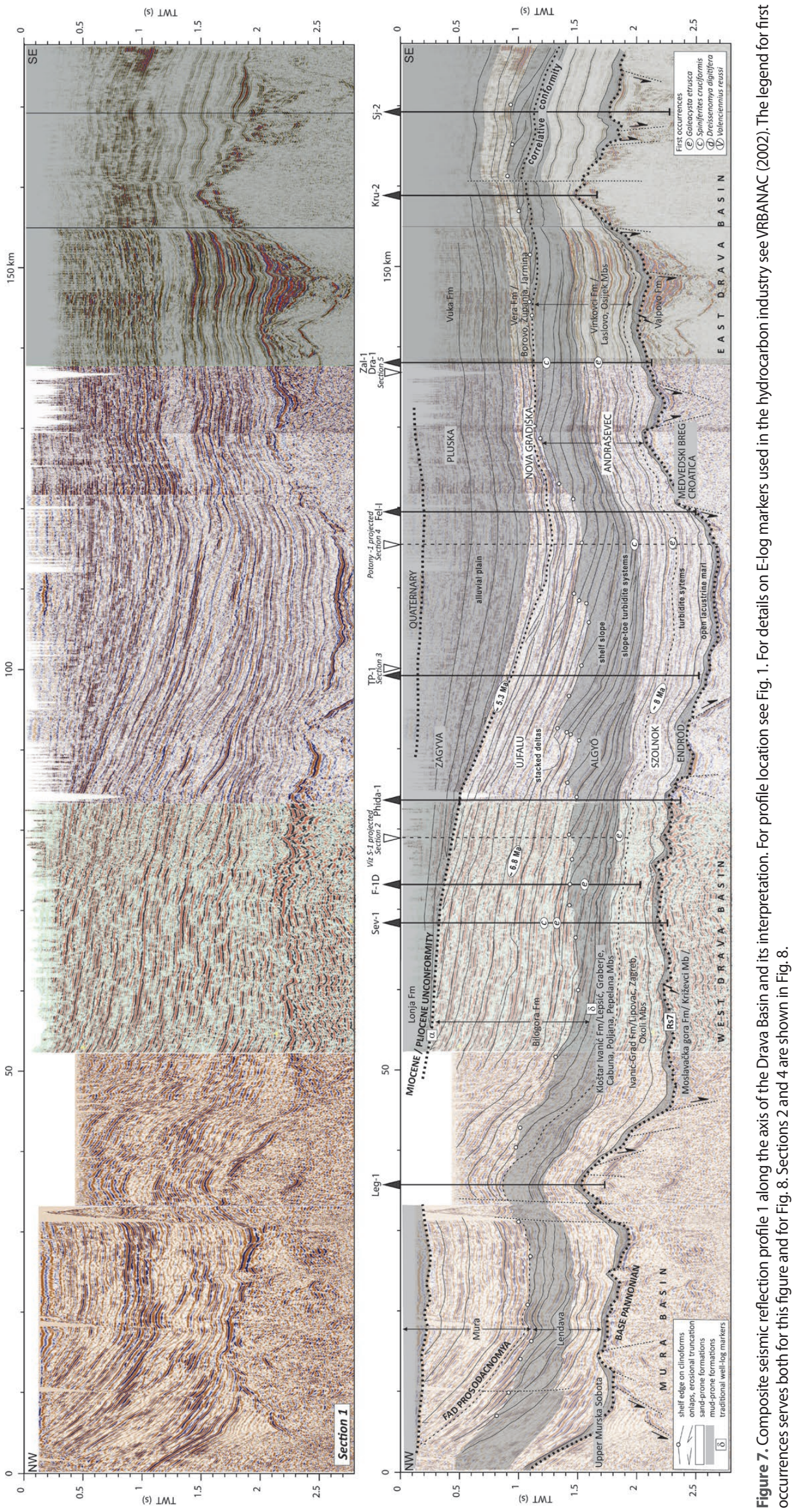

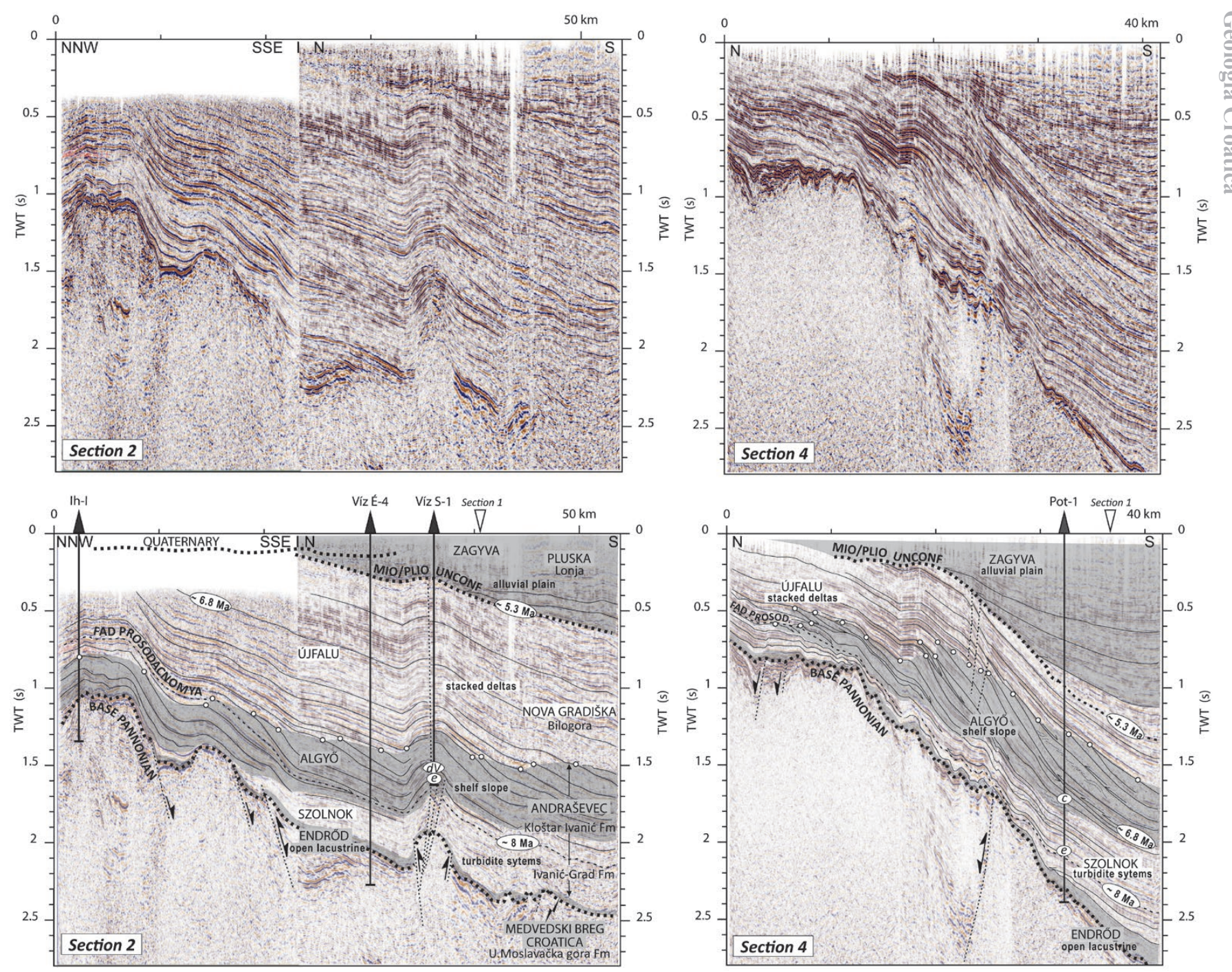

Figure 8. Composite seismic reflection profiles 2 and 4 from the margin to the centre of the Drava Basin and their interpretation. For profile locations see Fig. 1. For legend see Fig. 7.

Endröd Fm. in Hungary. The deep-water redepositional character of these conglomerates and sandstones by turbidity currents and debris flows is unambiguously shown by their sedimentary facies in the form of graded beds, complete and incomplete Bouma-sequences and widespread pebbly mudstones (BÉRCZI \& PHILLIPS, 1985; BÉRCZI et al., 1987; SZTANÓ et al, 2013b). In the deep parts of the SE Drava Basin such coarse-grained material was identified in wells (e.g. Sječe-2).

\subsubsection{Szolnok and Algyő Formations, Andraševec formation}

Deep-water sandstones and shales are classified as the Andraševec fm. in Croatia (KOVAČIĆ, 2004; KOVAČIĆ et al., 2004). The same deposits are assigned to the Szolnok and Algyö Fms. in Hungary, representing basin-centered turbidite systems, and slope shales together with the slope-related turbidite systems, respectively (BÉRCZI, 1988; JUHÁSZ, 1994; SZTANÓ et al., 2013b). These deep-water formations conformably overlie the Endrőd/Medvedski breg Fm., and they are conformably overlain by the Újfalu/Nova Gradiška Fm. They are the approximate equivalents of the middle and upper parts of the Ivanić-Grad Fm. and Kloštar Ivanić Fm. in the WDB, and the middle and upper parts of Vinkovci Fm. in the EDB.
The Szolnok Fm. and the lower part of the Algyö Fm. consist of very fine to medium-grained sandstones intercalated with siltstones (Fig. 6 D-F). The thickness of the sandstone beds varies from a few $\mathrm{cm}$ to several metres. Thin sandstone beds commonly alternate with siltstones a few centimetres in thickness. As the thickness of the sandstone beds increases, the frequency and thickness of silty interbeds decrease. $\mathrm{Cm}$ - to $\mathrm{dm}$-thick sandstone beds commonly show sedimentary structures including plane to cross-lamination, convolution and normal grading. Bouma sequences may occur. Thick beds are usually structureless or show faint water escape dishes or pipes. In the wells, $10-50 \mathrm{~m}$ thick sand-prone intervals alternate with a few tens of metres of mudprone intervals. Intervals of thick stacked sandstones with muddy intervals less than a few metres thick, occur at the upper part of the sand-prone succession, i.e. in the upper part of the turbidite systems (TP-1 and Fel-I). The thin-bedded heterolithic part of the successions represents the lobe margins of deep lacustrine turbidite systems, while thick-bedded to amalgamated sandstones were deposited at the lobe axis and off-axis regions (SZTANÓ et al., 2013b). The clastic detritus is mineralogically and structurally relatively mature and had been produced mostly by the weathering of siliciclastic sedimentary and metamorphic rocks of Alpine provenance (KOVAČIĆ \& GRIZELJ, 2006). 
In the Drava Basin it is difficult to distinguish the basin-centre and the slope-related turbidite systems, i.e. to determine the boundary between the Szolnok and Algyő Formations. In many depressions of the Pannonian Basin System, turbidites were deposited at several tens or even more than $100 \mathrm{~km}$ away from the feeding slope, where the source areas were often separated from the sink areas by the rough relief of the lake floor (cf. SZTANÓ et al., 2013a, b). In contrast, "toe-of-slope" turbidite systems of the Algyö Formation accumulated within a distance of 10-20 km from the slope (cf. SZTANÓ et al., 2013b). The latter are normally more sensitive to interactions between lacustrine base level and sedimentation rates, which determine the aggradation/progradation rates of the shelf-break slope. In the Drava Basin, however, the source of turbidites can be traced back to a distance of 100 $\mathrm{km}$ (see the "8 Ma" horizon or Galeacysta etrusca horizon in Fig. 7), as most of the system was not influenced by confining basin floor topography, at least not in the NW-SE axial direction. Therefore, the sand/shale ratio, or the stacking pattern of deep-water lobes might have been controlled by these allocyclic processes in addition to free autocyclic lobe switching. The exact linkage between the aforementioned processes needs further investigation. Seismically the Szolnok Fm. is characterized by parallel, low to moderate amplitude, moderate to high continuity seismic facies. In the lower part, reflections onlap apparently on the basement or on the 1-2 reflections thick Endröd Fm. The lower part of the Algyő Fm. is seismically similar, but several downlap reflections occur.

The upper part of the Algyö Fm. is composed of siltstone and clay marl with rare and thin intercalations of sandstone. Mudstones can be structureless or laminated, chaotic beds and slump folds are common (Ih-1). This part of the Algyő Formation corresponds to the inclined part of the clinoforms. The shelf-edge can usually be identified relatively easily (see marks in Figs. 7 and 8), where dipping reflectors deviate from overlying parallel ones. The dip of the clinoforms gradually decreases towards the bottomsets, but several downlaps help to distinguish the toe of slope. The height of the clinoforms can be used to estimate palaeo-water depth (POGÁCSÁS \& RÉVÉSZ, 1987; BALÁZS et al., 2018), which could reach $900-1300 \mathrm{~m}$ in the centre of the Drava Basin (KOVÁCS et al., under review).

The thickness of deposits related to the turbidite systems is $\sim 1000 \mathrm{~m}$ at Péterhida but exceeds $1300 \mathrm{~m}$ in the deepest part of the basin (wells TP and Fel). The uppermost $300-400 \mathrm{~m}$ is related directly to the toe of slope. On the Iharosberény high (Ih-1, Fig. $8 \mathrm{~A})$ a $100 \mathrm{~m}$ thick succession of toe-of-slope turbidites lies unconformably on Badenian limestones. The thickness of the monotonous mudstones (upper part of Algyő Fm.) over the basement highs can be as little as $300 \mathrm{~m}$ (Ih), while it attains 500-600 $\mathrm{m}$ in the central part of the basin.

The Szolnok, Algyő and Andraševec Formations contain a profundal mollusc fauna with Congeria banatica, "Dreissenomya" digitifera, Paradacna abichi, P. lenzi, "Pontalmyra" otiophora, Valenciennius reussi, accompanied by sublittoral species including C. czjzeki, C. zagrabiensis, C. croatica, and Lymnocardium majeri in the uppermost part of the Algyö and Andraševec Formations. In the ostracod assemblage Amplocypris reticulata, Candona (Caspiolla) lobata, C. (Pontoniella) paracuminata, smooth Hemicytheria marginata, Cyprideis ex gr. macrostigma, Cy. obesa, and nodose forms of the genus Cyprideis dominate, while the dinocyst assemblage consists of mainly endemic forms, such as $S$. bentorii "coniunctus", $S$. virgulaeformis, S. paradoxus, S. balcanicus, S. validus etc. The vertical ar- rangement of the facies within the Andraševec fm. and the accompanying fossil communities indicate the shallowing of the depositional environment.

The type areas where turbidite successions, i.e. the Andraševec fm. are exposed at the surface, are the Hrvatsko zagorje region and the Medvednica Mts. in NW Croatia. The formation is named after the Andraševec sections on the northern slopes of the Medvednica Mts. Spectacular outcrops of the turbidite system exist in the $\mathrm{N}$ Medvednica (Mirti/Hruševec; KOVAČIĆ et al., 2004). The lower part of the Petnja sand pit in the Dilj Mts. exposes a turbidite lobe with channels. (This outcrop was previously interpreted as a shallow delta and thus classified into the Nova Gradiška fm. (PAVELIĆ, 2001; KOVAČIĆ et al., 2017b)). No outcrops of the typical Algyő or Szolnok Fm. exist in SW Hungary. Sediments of a less than $100 \mathrm{~m}$ high slope, transitional in size between shelf break and and delta scale slopes, are exposed at the village of Szulimán (SZTANÓ et al., 2015).

\subsection{5. Újfalu Formation, Nova Gradiška formation}

The unit consists of an alternation of sand and calcareous silt layers with intercalations of lignite, variegated clay and gravel (Fig. 9). The sediments display a coarsening upward trend on the scale of 20-50 m thick intervals. The successions begin with bioturbated or laminated siltstones, overlain by thin-bedded silt-sand heterolithics. Slump folds and other soft-sediment deformation structures are common. The sands are structurally and mineralogically very similar to the sands of the Andraševec fm., indicating a common source area. Tabular to trough cross-bedding, symmetrical and asymmetrical cross-lamination, occasionally plane lamination are visible in the sandy units. Erosional surfaces are occasionally marked by small pebbles, mollusc debris and mud intraclasts. Cross-bedded sets may be stacked or alternate with cross-laminated sands. They mostly originated from the migration of dunes towards the SE. Rarely observed symmetrical to slightly asymmetrical cross-lamination is the result of current and wave action. The calcareous silts are massive, strongly bioturbated, and locally contain relics of horizontal lamination. Alternating fine-grained variegated sediments with pedogenic features, organic-rich sands-silts, gravels and lignite are characteristic of the upper part of the cycles and are more frequent in the upper parts of the formation. Subsurface data from both wells and seismic sections indicate that this unit attains a thickness of $1500 \mathrm{~m}$ in the NW Drava Basin, while it is only ca. $300 \mathrm{~m}$ thick in the SE (Fig. 7). The unit conformably overlies the Algyö/Andraševec Fm. In the Hrvatsko zagorje region and in the DB it is overlain by the Pluska fm., while in the Požega and Sava Basins by the Vrbova (Cernik) fm. (KOVAČIĆ, 2004; HALAMIĆ et al., 2019). Nova Gradiška fm. is the approximate equivalent of the Bilogora Fm. in the WDB and the Vera Fm. in the EDB.

The formation contains a littoral-sublittoral mollusc fauna with Congeria rhomboidea, C. balatonica, C. triangularis, Dreissena auricularis, Lymnocardium majeri, L. diprosopum, $L$. arpadense, L. hungaricum, L. rogenhoferi, Phyllocardium planum, Paradacna okrugici, various Prosodacnomya species, etc., as well as an ostracod assemblage with Hungarocypris pannonica and Candona (Camptocypria) lobata (KOVAČIĆ , 2004). The dinocyst assemblage is dominated by Impagidinium globosum, $\mathrm{Ga}$ leacysta etrusca, Pyxidinopsis psilata, Spiniferites virgulaeformis and Spiniferites cruciformis (BAKRAČ et al., 2012). The sediments of the unit were deposited during the late late Miocene and in the eastern part of the Drava Basin (Fig. 7) during the 

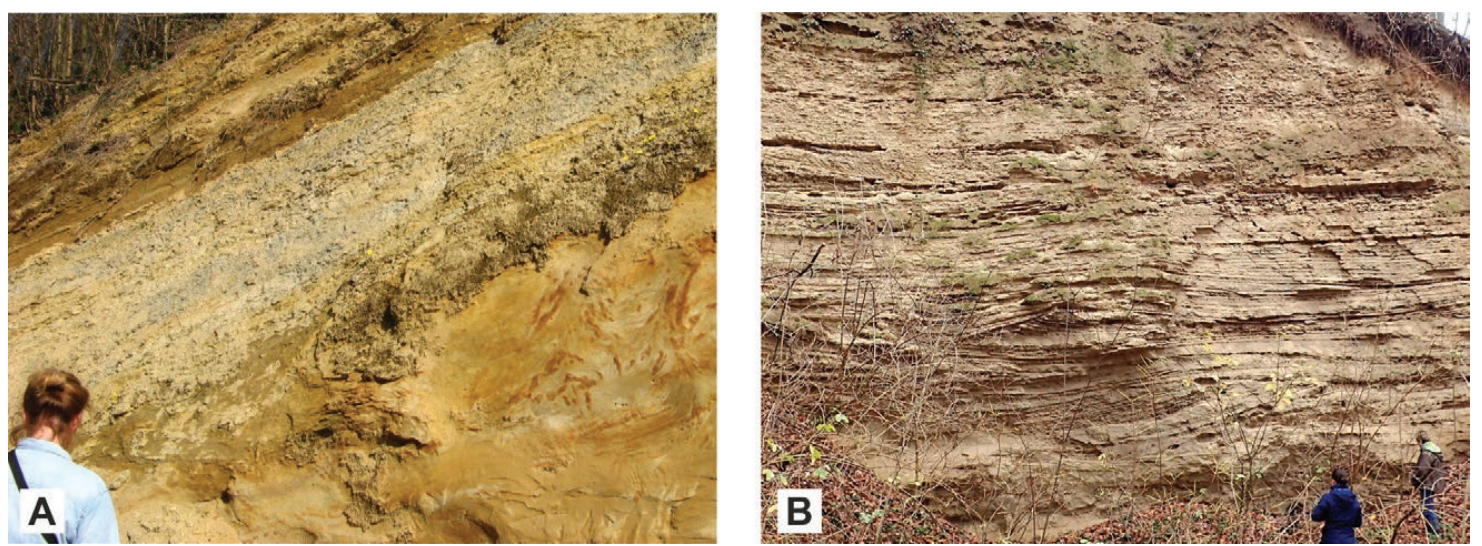

Figure 9. Újfalu Fm./Nova Gradiška fm. A) Sand with convolute bedding, silt, huminitic clay and lignite near Mučna Reka (Bilogora Hills, Croatia); B) Medium-grained cross-stratified sand to silt layers and channel forms west of the Mecsek Mts. (Mozsgó sand pit).

earliest Pliocene, based on the well to seismic correlation of the Miocene/Pliocene boundary (Fig. 7).

The formation was deposited as progradational delta lobes into the brackish Lake Pannon (SZTANÓ \& MAGYAR, 2007; SZTANÓ et al., 2013a), which were strongly influenced by sediment input from the NW. The siltstones and the heterolithics were deposited on the prodelta to the lower delta front. Most of the sand was deposited on mouth bars in the upper delta front environment. Sand deposition on the mouth bars was related to prolonged, frequent floods under humid climate conditions. Proximal bar sands continued distally and laterally to distal bar silts affected by strong bioturbation. Short-term advance, retreat and lateral shifting of the distributary channels and related mouth bars resulted in the vertical alternation of proximal and distal mouth bar deposits (KOVAČIĆ et al., 2004). Alternating finegrained sediments, sands, gravels and coals from the upper parts of the coarsening upward units were deposited in very shallow brackish interdistributary bays, in brackish wetlands or in freshwater marshes and ponds in a delta plain environment (JUHÁSZ \& MAGYAR 1992; JUHÁSZ, 1994; KOVAČIĆ et al., 2004).

The Nova Gradiška formation is named after sections located near the town of Nova Gradiška in western Slavonia. Apart from Slavonia, the type localities are in the Hrvatsko zagorje region (Hum Zabočki and Selnica sections) and in the Žumberak Mt. (Malunje section). The most representative surface occurrence in the Drava Basin is in the Našice quarry (STEVANOVIĆ, 1961). Some small occurrences are also detected in the northern
Krndija, Papuk and Bilogora Mts. In Hungary the Újfalu Fm. is usually exposed at some distance from the basement outcrops as a result of tilting and erosion caused by inversion-related uplift (SZTANÓ et al., 2015, 2016). The Mozsgó (Fig. 9B) and Himesháza (BUDAI et al., 2019) sand pits exhibit good outcrops, and the classic locality of Árpád (now Pécs-Nagyárpád; SZÓNOKY et al., 1999) also belongs to this formation.

\subsubsection{Zagyva Formation, Pluska formation}

The unit is composed of alternating packages of a few metres, occasionally few tens of metres thick cross-bedded, fining-upward sands or sandstones and a few metres to a few tens of metres thick successions of silt, clay and possibly lignite or huminitic clay (Fig. 10). Close to basement highs, gravels may also occur. The clays are often variegated and show signs of pedogenesis. Sands represent fluvial channel sediments, the major ones can be visualized on seismic images (Fig. 11), while the silt-clay units can be interpreted as abandoned channel-fills and/or floodplain fines. Though outcrops usually expose channel sands, the bulk of the formation is composed of fine-grained floodplain deposits (UHRIN \& SZTANÓ, 2007; NÁDOR \& SZTANÓ, 2011; UHRIN et al., 2011; ŠUJAN et al., 2020). The thickness of the unit could attain $1000 \mathrm{~m}$ in the central depression, e.g. near the borehole Fel-I (Fig. 7). In Croatia, in the Hrvatsko zagorje region, fluvial channel and floodplain sediments have been described as the Pluska fm. (KOVAČIĆ, 2004).
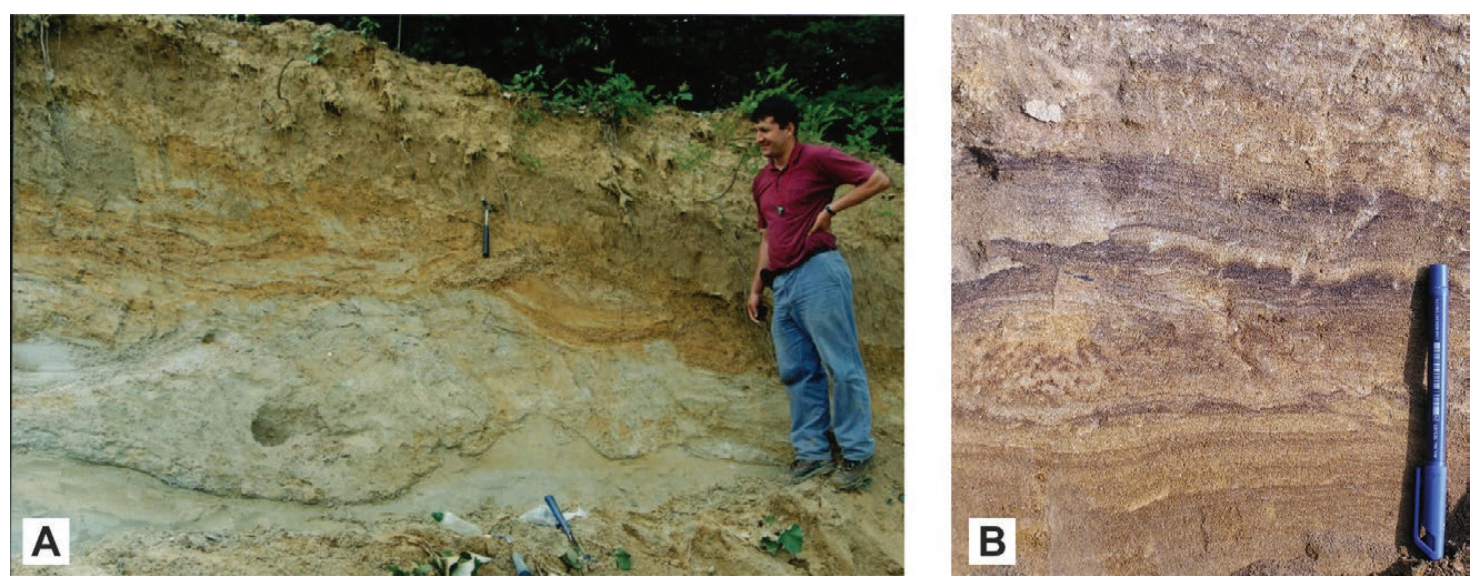

Figure 10. Pluska fm. A) Erosional contact between well sorted fine-grained sands of the Nova Gradiška fm. and the overlying poorly sorted gravels, sands and silts of the Pluska fm. Pluska, Hrvatsko zagorje. B) Bioturbated, pedogenetically altered sandy silt of the Pluska fm. Dubravica, Hrvatsko zagorje. 


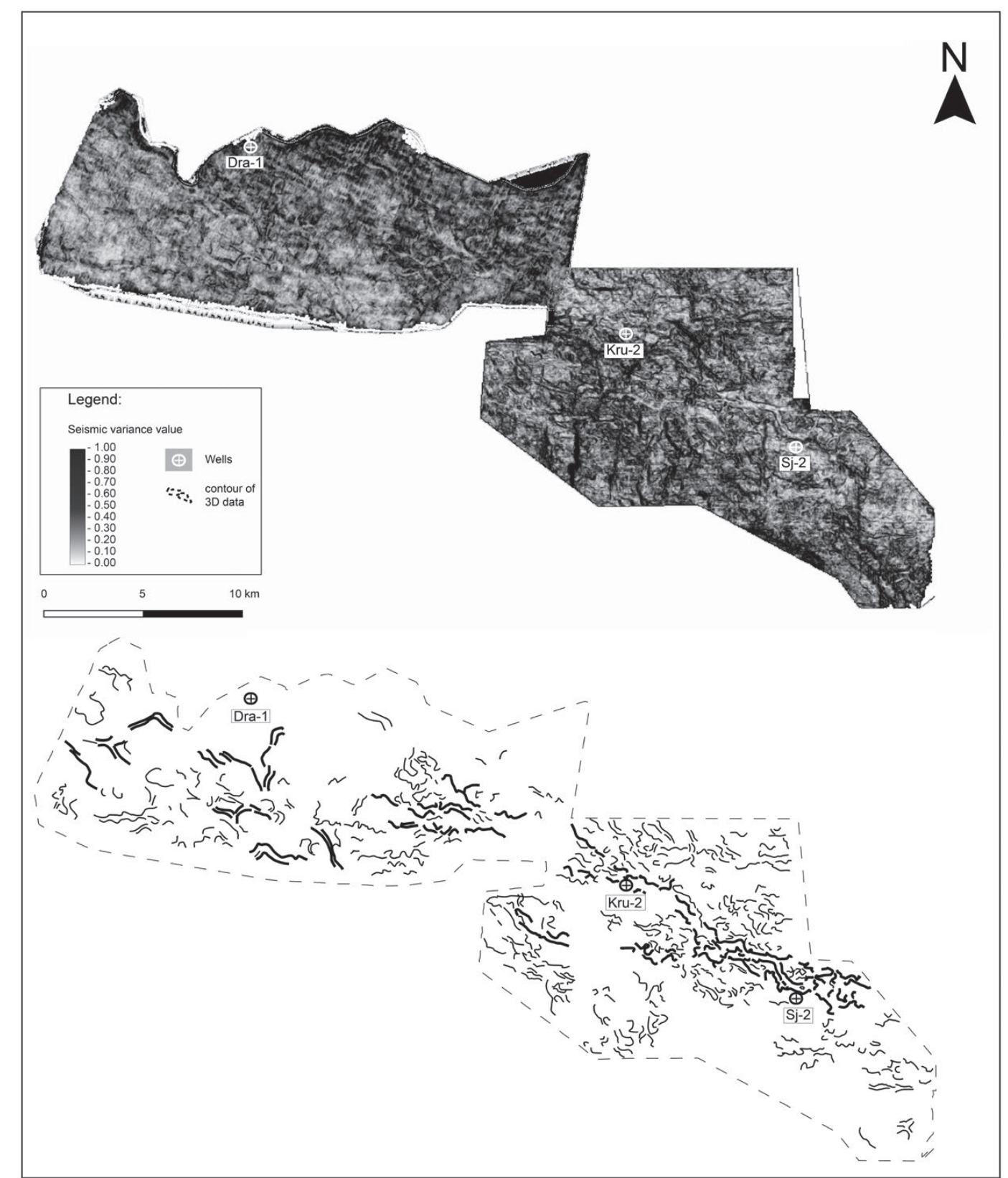

Figure 11. Seismic geomorphology shows a set of minor and major meandering linear elements on time slices extracted from flattened variance attribute 3D data, at a depth of approximately $650 \mathrm{~m}$. These are interpreted as fluvial channels on the alluvial plain building up the Zagyva/Pluska Fm.

The formation conformably overlies sediments of the Újfalu/ Nova Gradiška Fm. in the basin centre and unconformably in marginal areas (Figs. 7, 8). We do not possess fossil data from the formation which would allow us to constrain the age of the fluvial deposits. Based on the interpreted seismic sections of this study, the formation started to accumulate in the Pliocene (Fig. 7). In basinal areas it is difficult to separate Pliocene fluvial sediments from their Quaternary counterparts (e.g. NÁDOR \& SZTANÓ, 2011). The latter attain a thickness of nearly $300 \mathrm{~m}$ in the northern marginal part of the Drava Basin (e.g. borehole Görgeteg-I; KOLOSZÁR et al., 2001; KROLOPP, 2002), so they can be even thicker in the basin centre. Towards the basin margin, an unconformity separates the Zagyva Fm. from the Plio-Quaternary succession, while at the margins the formation is often missing due to pre-Quaternary denudation. The dating of the Plio-Quaternary fluvial succession and thus the upper age limit of the unconformity is uncertain: based on malacostratigraphy, magnetostratigra- phy and the presence of a possibly volcanogenic bentonite layer, fluvial sedimentation has been ongoing since at least 2-2.1 Ma, but a Pliocene age for the lowermost part of the succession above the unconformity cannot be excluded either (KOLOSZÁR et al., 2001; KROLOPP, 2002).

\section{BIOSTRATIGRAPHIC CORRELATIONS}

\subsection{Dinoflagellates}

The dinoflagellate stratigraphy of the Pannonian Stage (interpreted in the wide sense) was first established by SÜTÖSZENTAI (1982), and it has been continuously revised and improved since then (e.g. SÜTÖ-SZENTAI, 1988, 1990, 2000; SOLIMAN \& RIDING, 2017). This system was applied in Croatia with some modifications (KRIZMANIĆ in LUČIĆ et al., 2001; BAKRAČ, 2007; BAKRAČ et al., 2012).

The dinoflagellate zones are interval zones where subsequent zone boundaries are marked by the first appearance of novel mor- 
Table 1. First (lowest) recorded occurrences of the dinoflagellate species Galeacysta etrusca and Spiniferites cruciformis in the Drava Basin boreholes.

\begin{tabular}{lccc}
\hline \multicolumn{4}{c}{ Galeacysta etrusca } \\
\hline Well & Core or cutting & Two-Way-Time (ms) & Measured Depth (m) \\
\hline Dra-1 & cutting & 1680 & 2005 \\
\hline F-1D & core & 1565 & 1942 \\
\hline Potony-1 & cutting & 2065 & 2780 \\
\hline Sev-1 & cutting & 1330 & 1550 \\
\hline Víz-S-1* & core & 1570 & 2174
\end{tabular}

*representing data from Víz-S-1, Víz-S-2, Víz-D-1, and Her-D-1 wells, which lie on the same seismic reflector

\begin{tabular}{lccc}
\hline \multicolumn{4}{c}{ Spiniferites cruciformis } \\
\hline Well & Core or cutting & Two-Way-Time $(\mathrm{ms})$ & Measured Depth $(\mathrm{m})$ \\
\hline Dra-1 & cutting & 1232 & 1310 \\
\hline Potony-1 & cutting & 1714 & 2065 \\
\hline Sev-1 & cutting & 1210 & 1370 \\
\hline
\end{tabular}

phologies (species). There is consensus that the oldest Pannonian deposits are characterized by Spiniferites pannonicus, and, where present, by the prasinophyte Mecsekia ultima, which always occurs immediately above the Sarmatian sediments. The first appearances of Spiniferites oblongus and Pontiadinium pecsvaradense are both suitable for marking subsequent biozone boundaries. The following significant change in the dinocyst record is benchmarked with the more or less coeval first appearance of several forms, such as Spiniferites bentorii coniunctus, $S$. val$i d u$ s, S. balcanicus, and S. paradoxus. In this interval, either one (S. validus; BAKRAČ et al., 2012) or two (S. paradoxus or S. coniunctus and S. validus; SÜTÖ-SZENTAI, 1991; KRIZMANIĆ in LUČIĆ et al., 2001) or three (S. paradoxus, S. validus, S. tihanyensis; SÜTÖ-SZENTAI, 2000) biozones are distinguished. The first appearance of Galeacysta etrusca marks the base of a new biozone, and the subsequent first appearance of Spiniferites cruciformis is considered to be the youngest biostratigraphic marker in the sedimentary succession of Lake Pannon (BAKRAČ et al., 2012; Fig. 3).

Dinoflagellate data were collected from several wells in the Drava Basin (Fig. 12). When depicting dinoflagellate data on the seismic profiles, it is found that the older biozones correspond to relatively thin (a few tens of metres) sediment packages, which were deposited in deep water; these cannot be correlated along seismic reflectors between the wells because the uncertainty of the correlation and of the time/depth functions of wells is usually greater than the thickness of the individual biozones. The occurrences of Galeacysta etrusca and Spiniferites cruciformis, however, can be correlated between the wells. These two species were recovered from only a few hydrocarbon exploration wells (see Table 1) but they were commonly discovered in shallower boreholes from around the Villány Hills (SÜTÖ-SZENTAI, 1994, 2011). Correlations show that the deepest occurrences of these species in individual wells are not coeval, i.e. they do not represent the first appearance date (FAD) of the respective forms (Fig. 7). The stratigraphically deepest occurrence of G. etrusca was recorded in the deep-water deposits of the Potony-1 well, at $2780 \mathrm{~m}$, thus this occurrence approaches the best the real FAD of G. etrusca. The corresponding shelf edge above the slope is located some 65 $\mathrm{km}$ to the NW of the well along our Section 1 (Figs. 7, 1). The oldest occurrence of S. cruciformis, however, was found in well Sev-
1 , at $1370 \mathrm{~m}$ depth, in shelf deposits. The coeval shelf edge is identified at about $15 \mathrm{~km}$ to the SE along Section 1 (Fig. 7).

\subsection{Molluscs}

In the littoral deposits of Lake Pannon, a series of taxon-range zones (or rather lineage zones) were established on the basis of subsequent new morphologies within the supposedly anagenetic evolutionary lineage that starts with Lymnocardium edlaueri and ends with Prosodacnomya vodopici (MÜLLER \& MAGYAR, 1992; MAGYAR et al., 1999, 2000; MAGYAR \& GEARY, 2012). The boundary between the Lymnocardium decorum and Prosodacnomya carbonifera zones, defined by the first appearance of the genus Prosodacnomya, could be clearly identified on seismic profiles in the Budafa area, immediately east of the northwesternmost tip of Section 1 (Fig. 7), based on the data provided by BARNABÁS \& STRAUSZ (1991) on the occurrences of $L$. decorum and Prosodacnomya in this region. This dataset was completed with scattered unpublished information on the presence of these forms in hydrocarbon exploration wells from the northern side of the Drava Basin. Based on the above data, we traced this biozone boundary on seismic profiles across the entire study area as shown in Figs. 7 and 8. This seismic horizon turned out to be only very slightly older than the oldest occurrence of Galeacysta etrusca in the Potony-1 well.

The profundal deposits of Lake Pannon were divided into the older Congeria banatica zone, characterized by C. banatica and various members of the evolutionary lineage from Radix to Provalenciennesia, and the younger "Dreissenomya" digitifera zone, characterized by "D." digitifera and Valenciennius (MAGYAR et al., 1999; MAGYAR \& GEARY, 2012; Fig. 3). In the Drava Basin, both biozones are present. The shelf-break slope, however, belongs to the younger " $D$." digitifera zone everywhere in the Drava Basin (Figs. 8, 13).

\section{GEOCHRONOLOGY}

Our means to date the thick upper Neogene succession of the Drava Basin are severely limited. Of the relevant biostratigraphic boundaries, only the FAD of Prosodacnomya was reliably dated. The earliest representative of this genus, $P$. carbonifera was recovered from a sedimentary inclusion embedded into volcanic material in the Tihany peninsula, Lake Balaton (SZTANÓ et al., 2013a). The Tihany maar volcano is known to have started its activity $7.92 \pm 0.22$ to $7.96 \pm 0.03 \mathrm{Ma}$ ago (as assessed by K/Ar and Ar/Ar analyses by BALOGH \& NÉMETH (2005) and WIJBRANS et al. (2007), respectively). Therefore, the first appearance datum of Prosodacnomya could be determined as ca. $8 \mathrm{Ma}$ (Fig. 3). This interpretation was recently confirmed by magnetostratigraphic investigations in central Hungary (KELDER et al., 2018; MAGYAR et al., 2019). The FAD of Galeacysta etrusca has long been supposed to be very close to that of Prosodacnomya (MAGYAR \& GEARY, 2012), although the two fossils never occur in the same layer due to their originally highly different environmental requirements (Fig. 3).

The biostratigraphic boundary between the Congeria banatica and "Dreissenomya" digitifera Zones in the profundal zone of Lake Pannon was tentatively dated as ca. 9.6 Ma (MAGYAR et al., 1999; MAGYAR \& GEARY, 2012; Fig. 3). In the Drava basin, this boundary runs within the Endröd Formation; the corresponding shelf-break slope is located in NW Hungary (MAGYAR et al., 2013).

An additional chronological tie point can be the age of the significant unconformity that is observed within the late Neogene 

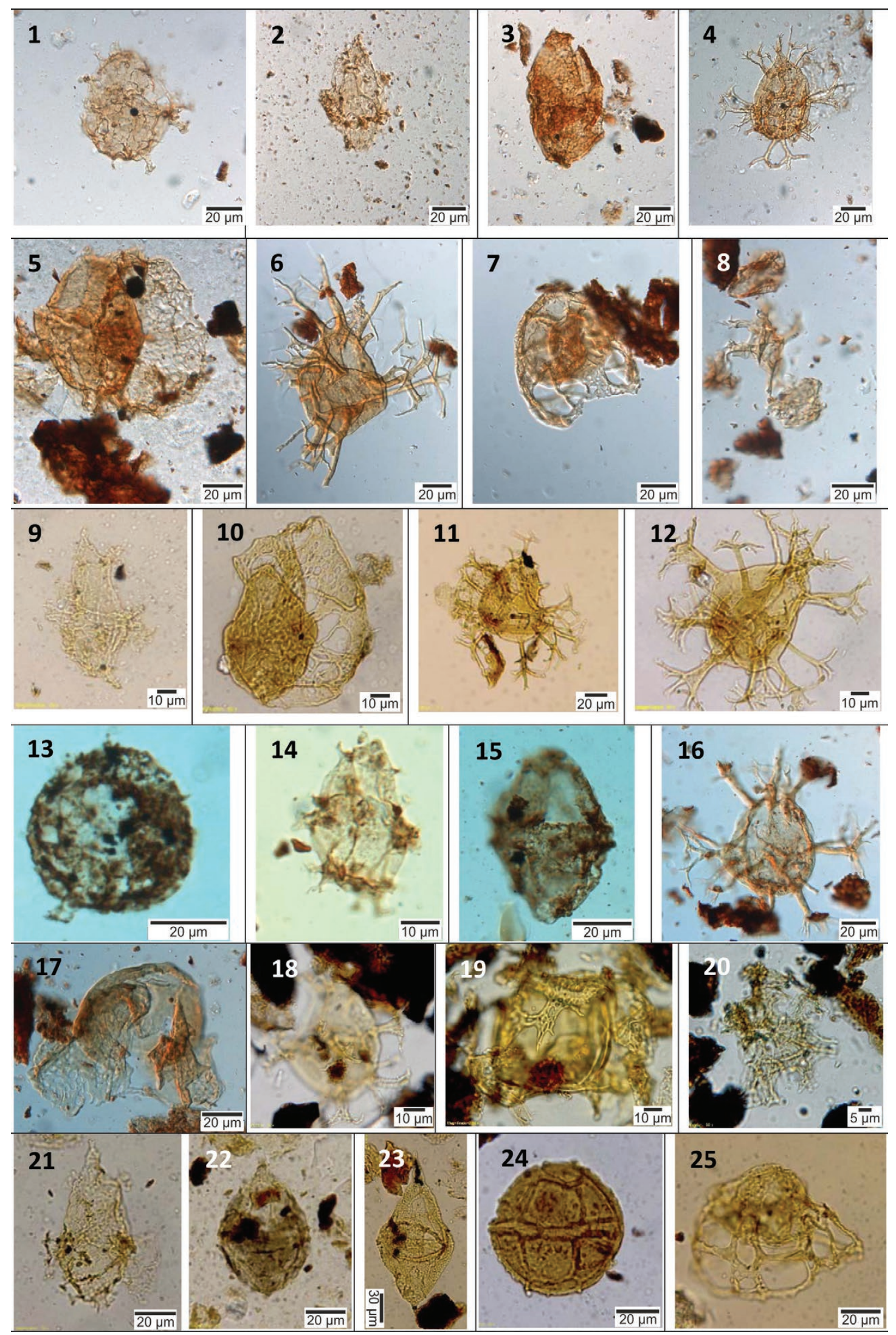

Figure 12. Dinoflagellates from wells in the Drava Basin.

1 Spiniferites pannonicus, Dravica-1 well, 2880-2885 m, 2 Spiniferites oblongus, Dravica-1, 2840-2845 m, 3 Pontiadinium pecsvaradensis, Dravica-1, 2820-2825 m, 4 Spiniferites bentorii coniunctus, Dravica-1, 2800-2805 m, 5 Spiniferites balcanica, Dravica-1, 2695-2700 m, 6 Spiniferites validus, Dravica-1, 2190-2195 m, 7 Galeacysta etrusca, Dravica-1, 1300-1310 m, 8 Spiniferites cruciformis, Dravica-1, 1300-1310 m, 9 Spiniferites oblongus, Legrad-1J, 2076-2081 m, 10 Spiniferites balcanica, Legrad-1J, 1659-1665 m, 11 Spiniferites bentorii coniunctus, Legrad-1J, 1659-1665 m, 12 Spiniferites validus, Legrad-1J, interval 1659-1665 m, 13 Spiniferites pannonicus, Potony-1, $3260 \mathrm{~m}, 14$ Spiniferites oblongus, Potony-1, $3204 \mathrm{~m}$, 15 Pontiadinium pecsvaradensis, Potony-1, $3174 \mathrm{~m}$, 16 Spiniferites bentorii coniunctus, Potony-1, 3040 m, 17 Galeacysta etrusca, Potony-1, 2780 m, 18 Achomosphaera andalusiensis, Severovci-1, 2750-2760 m, 19 Galeacysta etrusca, Severovci-1, 480-490 m, 20 Spiniferites cruciformis, Severovci-1, 920-930 m, 21 Spiniferites oblongus, Zalata-K-1, 2540 m, 22 Pontiadinium pecsvaradensis, Zalata-K-1, 2500 m, 23 Pontiadinium inequicornutum, Zalata-K-1, 2460 m, 24 Impagidinium globosum, Zalata-K-1, 1980 m, 25 Galeacysta etrusca, Zalata-K-1, 1640 m. 

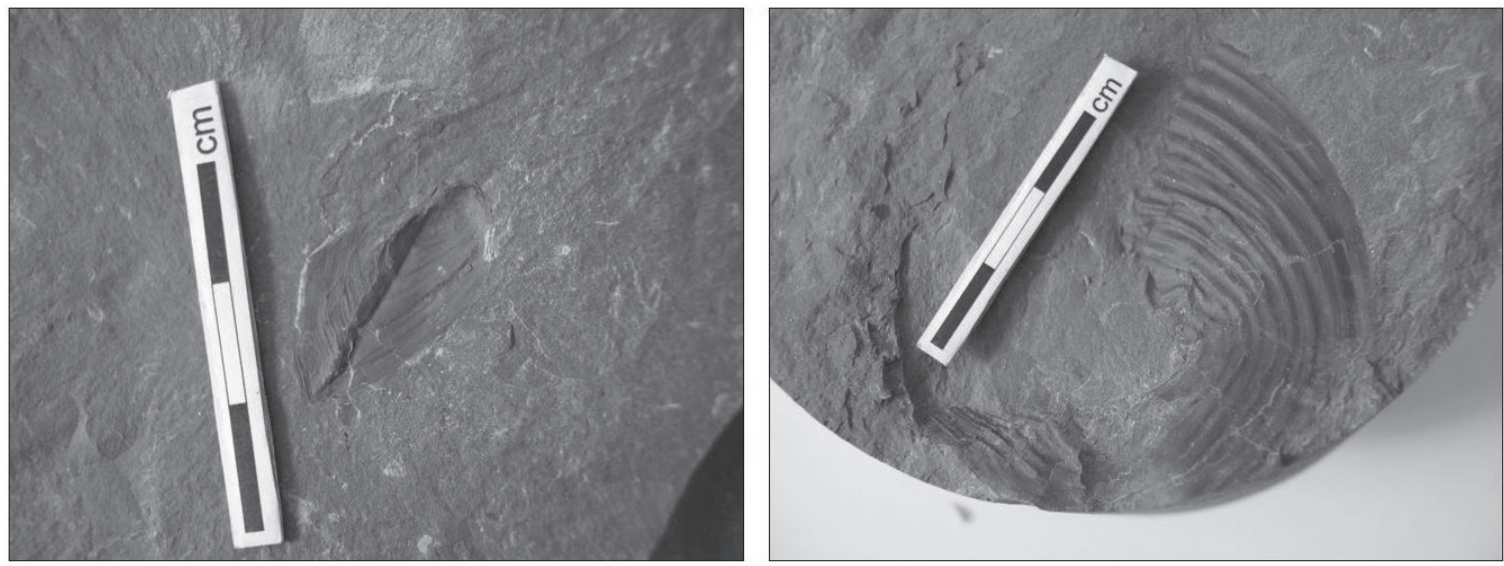

Figure 13. "Dreissenomya" digitifera and Valenciennius reussi from the Víz-S-1 well, $2060 \mathrm{~m} \mathrm{MD.} \mathrm{The} \mathrm{sample} \mathrm{is} \mathrm{from} \mathrm{the} \mathrm{bottom} \mathrm{part} \mathrm{of} \mathrm{the} \mathrm{Algyő} \mathrm{Formation} \mathrm{(see}$ Fig. 8), which belongs here to the Galeacysta etrusca biozone. The presently $500 \mathrm{~m}$ thickness of the Algyö clinoforms in this part of the basin indicates that these benthic animals lived in the profundal zone of Lake Pannon, at a water depth of 700-900 m (for clinoform decompactions see BALÁZS et al., 2018).

succession of the Drava Basin in its northern margin (UJSZÁSZI \& VAKARCS, 1993; SACCHI et al., 1998, 1999). This unconformity looks very similar to, and seems to be geographically connected with another unconformity in the sedimentary succession of the central Pannonian Basin System (,Great Hungarian Plain”), where it was magnetostratigraphically dated between 4.6 and 6.8 Ma (MAGYAR \& SZTANÓ, 2008 and references therein). As the vertebrate fauna was Miocene below and Pliocene above the unconformity in several boreholes, its basinward conformity was considered to roughly correspond to the Miocene-Pliocene boundary (5.3 Ma; MAGYAR \& SZTANÓ, 2008). If we tentatively accept this approach, the $5.3 \mathrm{Ma}$ horizon can be traced across much of the Drava Basin within the shelf deposits, whereas in the easternmost part of the basin it crosses the shelf edge and continues in the deep-water deposits (Fig. 7).

\section{CONCLUSIONS}

The sedimentary infill of the Drava Basin is composed of the same suite of sedimentary units both on the Hungarian and Croatian sides, similarly to other parts of the Pannonian Basin System: local transgressive coarse clastics around emergent basement highs, open-to-deep water calcareous marls, turbidite sandstones, slope mudstones, and sand to clay sequences deposited in delta plain and alluvial environments. These units can be well correlated across the basin.

The comparison of the various rock units in boreholes with seismic profiles evidenced that the formation boundaries are time-transgressive in the Drava Basin, similarly to other studied regions of the Pannonian Basin System.

At present, dinoflagellate biostratigraphy and seismic stratigraphy are the only tools to subdivide and chronostratigraphically correlate the deep-water deposits in the Drava Basin. When plotting the first (lowest) occurrences of individual species against the seismic database, however, it becomes evident that investigations from scattered drill cores and cuttings can easily fail to identify the first appearance datum of any stratigraphic marker species, therefore special attention is required for the interpretation of biozone boundaries in such boreholes.

According to the interpreted seismic network, sediment transport directions in the study area varied between $\mathrm{N}$ to $\mathrm{S}$ and W to E. Seismic correlation of the biochronologically first appearance datum of the bivalve genus Prosodacnomya from outside the study area suggests that the oldest clinoform surfaces in the Mura Basin are more than 8 Ma old. The 8 Ma old shelf edge slope (dated by the FAD of Prosodacnomya) is located in the northernmost part of the Drava Basin, between the wells Leg-1J and Sev-1 in Croatia and between wells Ib-I and Víz-É-4 in Hungary. The youngest clinoforms detected in the southeasternmost part of the Drava Basin are younger than the - supposedly - MiocenePliocene unconformity, thus they might be Pliocene in age.

\section{ACKNOWLEDGEMENT}

Research was carried out within the framework of the HungarianCroatian bilateral project ,Stratigraphy and correlation of Upper Miocene - Pliocene sediments along the Croatian-Hungarian border" (TÉT_16-1-2016-0004), and was also supported by the OTKA/NKFIH (Hungarian National Research, Development and Innovation Office) projects PD104937 and 116618, by the Croatian Science Fundation under the project IP-2019-04-7042, and by the Bolyai PD fellowship of the Hungarian Academy of Sciences for KS. Core inspection of some major wells was financed by the Higher Education Institutional Excellence Programme of the Ministry of Human Capacities in Hungary, within the framework of the 3rd thematic programme of the University of Pécs. Donation of the academic license of Schlumberger Petrel software, and data usage permission assigned by Croatian Hydrocarbon Agency and Ministry of Economy, Entrepreneurship and Crafts for PhD research (MŠ) interconnected to this scientific project is highly appreciated. The aforementioned $\mathrm{PhD}$ research was also supported by intergovernmental scholarships of the Hungarian Tempus Public Foundation, part of these results are incorporated into this article. MOL Hungarian Oil and Gas Plc. and INA-Industrija Nafte d.d. are acknowledged for their permission to use seismic and borehole data for our study. This is MTAMTM-ELTE Paleo contribution No 328. We are grateful to Oleg MANDIC and an anonymous reviewer for their thorough reviews, which greatly improved the manuscript.

\section{REFERENCES}

BADICS, B. \& VETÖ, I. (2012): Source rocks and petroleum systems in the Hungarian part of the Pannonian Basin: The potential for shale gas and shale oil plays.- Marine and Petroleum Geology, 31, 53-69. doi: 10.1016/j.marpetgeo.2011.08.015

BASCH, O. (2009): Klastiti i ugljen (pont - M7) [Clastites and coal (Pontian - M7) - in Croatian].- In: VELIĆ, I. \& VLAHOVIĆ, I. (eds.): Tumač Geološke karte Republike Hrvatske 1:300.000 [Explanatory note of the Basic Geological Map of the Republic of Croatia 1:300000 - in Croatian]. Croatian Geological Survey, Zagreb, $141 \mathrm{p}$. 
BAKRAČ, K. (2005): Palinološka karakterizacija naslaga srednjeg i gornjeg miocena jugozapadnog dijela Panonskog bazena [Palynology of the middle and upper Miocene deposits from the south-western parts of the Pannonian Basin - in Croatian with English Summary].- Unpubl. PhD Thesis, University of Zagreb, 173 p.

BAKRAČ, K. (2007): Middle and Upper Miocene palynology from the south-western parts of the Pannonian basin.- Joannea Geologie und Paläontologie, 9, 11-13.

BAKRAČ, K., KOCH, G. \& SREMAC, J. (2012): Middle and Late Miocene palynological biozonation of the south-western part of Central Paratethys (Croatia).--Geologia Croatica, 65/2, 207-222. doi: 10.4154/GC.2012.12

BALÁZS, A., MATENCO, L., MAGYAR, I., HORVÁTH, F. \& CLOETINGH, S. (2016): The link between tectonics and sedimentation in back-arc basins: new genetic constraints from the analysis of the Pannonian Basin.- Tectonics, 35, 1526-1559. doi: 10.1002/2015TC004109

BALÁZS, A., MAGYAR, I., MATENCO, L., SZTANÓ, O., TŐKÉS, L. \& HORVÁTH, F. (2018): Morphology of a large paleo-lake: Analysis of compaction in the Miocene-Quaternary Pannonian Basin.- Global and Planetary Change, 171, 134-147. doi: 10.1016/j.gloplacha.2017.10.012

BALOGH, K. \& NÉMETH, K. (2005): Evidence for the Neogene small-volume intracontinental volcanism in Western Hungary: K/Ar geochronology of the Tihany Maar Volcanic Complex.- Geologica Carpathica, 56, 91-99.

BARNABÁS, K. \& STRAUSZ, L. (1991): A délnyugat-dunántúli pannonikum [The Pannonian in SW Transdanubia - in Hungarian].- Földtani Közlöny, 119, 191-306.

BÉRCZI, I. (1988): Preliminary sedimentological investigation of a Neogene depression in the Great Hungarian Plain.- In: ROYDEN, L.H. \& HORVÁTH, F. (eds.): The Pannonian Basin. AAPG Memoir, 45, 107-116

BÉRCZI, I. \& PHILLIPS, R.L. (1985): Process and depositional environments within Neogene deltaic-lacustrine sediments, Pannonian Basin, Southeast Hungary.-Geophysical Transactions, 31, 55-74.

BÉRCZI, I., DANK, V., GAJDOS, I., PAP, S., RÉVÉSZ, I., SZENTGYÖRGYI, K. \& VÖLGYI, L. (1987): Ablagerungen der Kunság-Stufe (Pannonien s. str.) auf der Grossen Ungarischen Tiefebene.- In: JÁMBOR, Á. (ed.): Geologische Charakterisierung der Ablagerungen der Kunság-Stufe in Ungarn.- Annals of the Hungarian Geological Institute, 69, 179-198.

BUDAI, S., SEBE, K., NAGY, G., MAGYAR, I. \& SZTANÓ, O. (2019): Interplay of sediment supply and lake-level changes on the margin of an intrabasinal basement high in the Late Miocene Lake Pannon (Mecsek Mts., Hungary).-- International Journal of Earth Sciences, 108, 2001-2019, doi: 10.1007/s00531-019-01745-3

CHIKÁN, G. (1991): Die Känozoischen Ablagerungen des westlichen Mecsekgebirges.Annals of the Geological Institute of Hungary, LXXII, Budapest, $281 \mathrm{p}$.

CSÁSZÁR, G. (ed.) (1997): Basic litostratigraphic units of Hungary.- Geological Institute of Hungary, Budapest, $114 \mathrm{p}$.

CSILLAG, G. \& SZTANÓ, O. (2015a): Upper Miocene.- In: KERCSMÁR, ZS. (ed.), BUDAI, T., CSILLAG, G., SELMECZI, I. \& SZTANÓ, O.: Surface geology of Hungary. Explanatory notes to the Geological map of Hungary (1:500 000). Geological and Geophysical Institute of Hungary, Budapest, 45-50.

CSILLAG, G. \& SZTANÓ, O. (2015b): Miocene-Pliocene.- In: KERCSMÁR, ZS. (ed.), BUDAI, T., CSILLAG, G., SELMECZI, I. \& SZTANÓ, O.: Surface geology of Hungary. Explanatory notes to the Geological map of Hungary (1:500 000). Geological and Geophysical Institute of Hungary, Budapest, 50-51.

CSONTOS, L., BENKOVICS, L., BERGERAT, F., MANSY, J-L. \& WÓRUM, G. (2002): Tertiary deformation history from seismic section study and fault analysis in a former European Tethyan margin (the Mecsek-Villány area, SW Hungary).- Tectonophysics, 357/1-4, 81-102. doi: 10.1016/S0040-1951(02)00363-3

CROATIAN GEOLOGICAL SURVEY (2009): Geološka karta Republike Hrvatske M 1:300.000 [Basic Geological Map of the Republic of Croatia 1:300000 - in Croatian].- Croatian Geological Survey, Department of Geology, Zagreb.

DEZSÖ, J., RAUCSIK, B. \& VICZIÁN, I. (2007): Villányi-hegységi karsztos hasadékkitöltések szemcseösszetételi és ásványtani vizsgálata [Granulometric and mineralogical analysis of karstic fissure filling sediments in the Villány Mts. (S Hungary) - in Hungarian].- Acta GGM Debrecina, 2, 151-180.

FILJAK, R., PIKIJA, M., AVANIĆ, R., BAKRAČ, K. \& MIKNIĆ, M., PAVELIĆ, D., BRKIĆ, M. \& BELAK, M. (2016a): Osnovna geološka karta Republike Hrvatske mjerila 1 : 50 000, list Slavonska Požega 3 [Basic Geological Map of the Republic of Croatia 1:50000, Slavonska Požega 3 sheet - in Croatian].-Croatian Geological Survey, Department of Geology, Zagreb.

FILJAK, R., PIKIJA, M., AVANIĆ, R., BAKRAČ, K. \& MIKNIĆ, M. (2016b): Osnovna geološka karta Republike Hrvatske mjerila $1: 50$ 000, list Slavonska Požega 4 [Basic Geological Map of the Republic of Croatia 1:50000, Slavonska Požega 4 sheet - in Croatian].- Croatian Geological Survey, Department of Geology, Zagreb.

GEARY, D.H., MAGYAR, I. \& MÜLLER, P. (2000): Ancient Lake Pannon and its Endemic Molluscan Fauna (Central Europe; Mio-Pliocene).- In: ROSSITER, A. \& KAWANABE, H. (eds.), Ancient Lakes: Biodiversity, Ecology, and Evolution. Advances in Ecological Research, 3, 463-482. doi: 10.1016/S0065-2504(00)31025-X

GORJANOVIĆ-KRAMBERGER, D. (1890): Die Praepontischen Bildungen des Agramer Gebirges.- Glasn. Hrv. Narv. Društva, 5, 151-164.
HABLY, L. \& SEBE, K. (2016): A late Miocene thermophilous flora from Pécs-Danitzpuszta, Mecsek Mts., Hungary. Neues Jahrbuch für Geologie und Paläontologie, 279/3, 261-271. doi: 10.1127/njgpa/2016/0554

HALAMIĆ, J., BELAK, M., PAVELIĆ, D., AVANIĆ, R., FILJAK, R., ŠPARICA, M., BRKIĆ, M., KOVAČIĆ, M., VRSALJKO, D., BANAK, A. \& CRNKO, J. (2019): Osnovna geološka karta Republike Hrvatske mjerila $1: 50000$ - Požeška gora [Basic Geological Map of the Republic of Croatia 1:50000 - Požeška gora - in Croatian].- Croatian Geological Survey, Department of Geology, Zagreb.

HÁMOR, G. (1970): Das Miozän des östlichen Mecsek-Gebirges.- Annals of the Geological Institute of Hungary, 53/1, 371 p.

HEĆIMOVIĆ, I., MARSI, I., BANAK, A., CHIKÁN G., FERIĆ, P., GRIZELJ, A., HORVAT, M., KOLOSZÁR, L. \& MAGYARI, Á. (2010): Correlation of Quaternary and Tertiary sediments of Drava-valley at Sellye-Slatina sheet, scale 1:100 000.- In: 4th Croatian Geological Congress, Sibenik, 14-15. 10. 2010. Abstract Book. Croatian Geological Survey, Zagreb, 369-370.

HILGEN, F J., LOURENS, L.J., VAN DAM, J.A., BEU, A.G., BOYES, A.F., COOPER, R.A., KRIJGSMAN, W., OGG, J.G., PILLER, W.E. \& WILSON, D.S. (2012): The Neogene Period.- In: GRADSTEIN, F. M., OGG, J.G., SCHMITZ, M. \& OGG, G. (eds.): The Geologic Time Scale. Elsevier, 923-978. doi: 10.1016/B978-0-44459425-9.00029-9

HORVÁTH, F., BADA, G., SZAFIÁN, P., TARI, G., ÁDÁM A. \& CLOETHING, S. (2006): Formation and deformation of the Pannonian basin: Constraints from observational data.- In: GEE, D.G. \& STEPHENSON, R.A. (eds): European Lithosphere Dynamics, Geological Society, London, Memoirs, 32, 191-206. doi: 10.1144/GSL.MEM.2006.032.01.11

HORVÁTH, F., PAP, N., REMÉNYI, P. \& TÓTH, T. (2012): Geothermal Resource Assessment of the Drava Basin. IDResearch Kft. / Publikon Publishers, Pécs, 222 p. https://secco2.eu/sites/default/files/digital_library/2018-10/LBDB-GeothermalResourceAssessmentoftheDravaBasin.pdf

HORVÁTH, F., DULIĆ, I., VRANKOVIĆ, A., KOROKNAI, B., TÓTH T., WÓRUM, G. \& KOVÁCS, G. (2018): Overview of geologic evolution and hydrocarbon generation of the Pannonian Basin.- Interpretation, February 2018, SB111-122. doi: 10.1190/INT-2017-0100.1

JENKO, K. (1944). Stratigrafski i tektonski snošaj Pliocena južnog pobočja Požeške gore i Kasonje brda.- Vjestnik Hrvatskog državnog geoložkog zavoda i Hrvatskog državnog geoložkog muzeja, 2/3, 89-159.

JUHÁSZ, GY. (1994): Comparison of the sedimentary sequences in Late Neogene subbasins in the Pannonian Basin, Hungary.- Földtani Közlöny, 124, 341-365.

JUHÁSZ, GY. (1998): A magyarországi neogén mélymedencék pannóniai képzödményeinek litosztratigráfíja. [Lithostratigraphy of Pannonian formations of Neogene deep basins in Hungary - in Hungarian].- In: BÉRCZI, I. \& JÁMBOR, Á. (eds.): Magyarország képződményeinek rétegtana [Stratigraphy of geological formations of Hungary]. MOL Rt. - Geological Institute of Hungary, Budapest, 469-484.

JUHÁSZ, GY. \& MAGYAR, I. (1992): Review and correlation of the Late Neogene (Pannonian s.1.) lithofacies and mollusc biofacies in the Great Plain, eastern Hungary.Földtani Közlöny, 122, 167-194.

KELDER, N.A., SANT, K., DEKKERS, M. J., MAGYAR I., VAN DIJK, G.A., LATHOUWERS, Y.Z., SZTANÓ, O. \& KRIJGSMAN, W. (2018): Paleomagnetism in Lake Pannon: problems, pitfalls, and progress in using iron sulfides for magnetostratigraphy.- Geochemistry, Geophysics, Geosystems, 19, 3405-3429. doi: 10.1029/2018GC007673

KLEB, B. (1973): Geologie des Pannons im Mecsek.-Annals of the Geological Institute of Hungary, LIII/3, 750-943.

KOLOSZÁR, L., LANTOS, M. \& CHIKÁN, G. (2001): A görgeteg G-1 és az udvari U2A fúrások fúrások negyedidőszaki képzödményeinek párhuzamositása [Correlation of the Quaternary sediments in the Görgeteg $G-1$ and the Udvari U2A boreholes - in Hungarian].- Földtani Közlöny, 131/3-4, 443-460.

KONRÁD, GY. \& SEBE, K. (2010): New Records of Young Tectonic Phenomena in the Western Mecsek Mts. and their Surroundings.- Földtani Közlöny, 140/2, 445-468.

KÖRÖSSY, L. (1989): A Dráva-medencei kőolaj- és földgázkutatás földtani eredményei [Hydrocarbon geology of the Drava Basin in Hungary - in Hungarian].- Általános Földtani Szemle, 24, 3-121.

KORPÁS-HÓDI, M. (1987): Korrelationsmöglichkeit der jungen Neogenbildungen Ungarns.- Annals of the Geological Institute of Hungary, 69, 435-452.

KORPÁSNÉ HÓDI, M. (1998): Medenceperemi pannóniai s.l. üledékes formációk rétegtana [Stratigraphy of Pannonian s.l. sedimentary formations of the basin margins - in Hungarian].- In: BÉRCZI, I. \& JÁMBOR, Á. (eds.): Magyarország képzödményeinek rétegtana [Stratigraphy of geological formations of Hungary]. MOL Rt.- Geological Institute of Hungary, Budapest, 453-468.

KOVAČIĆ, M. (2004): Sedimentologija gornjomiocenskih naslaga jugozapadnog dijela Panonskog bazena [Sedimentology of the upper Miocene deposits from the southwestern part of Pannonian basin - in Croatian with an English Summary].- Unpubl. PhD. Thesis, University of Zagreb, $203 \mathrm{p}$. 
KOVAČIĆ, M. \& GRIZELJ, A. (2006): Provenance of the Upper Miocene clastic material in the southwestern part of the Pannonian Basin.- Geologica Carpathica, 57/6, 495-510.

KOVAČIĆ, M. \& PAVELIĆ, D. (2017): Neogene stratigraphy of the Slavonian Mountains.- In: KOVAČIĆ, M., WACHA, L. \& HORVAT, M. (eds): 7th International Workshop Neogene of Central and South-Eastern Europe, 28-31 5. 2017. Field Trip Guidebook, Croatian Geological Society, Zagreb, 5-9.

KOVAČIĆ, M., ZUPANIČ, J., BABIĆ, LJ., VRSALJKO, D., MIKNIĆ, M., BAKRAČ, K., HEČIMOVIĆ, I., AVANIĆ, R. \& BRKIĆ, M. (2004): Lacustrine basin to delta evolution in the Zagorje Basin, a Pannonian sub-basin (Late Miocene: Pontian, NW Croatia).- Facies, 50/1, 19-33.

KOVAČIĆ, M., HORVAT, M., PIKIJA, M. \& SLOVENEC, D. (2011): Composition and provenance of Neogene sedimentary rocks of Dilj gora Mt. (south Pannonian Basin, Croatia).- Geologia Croatica, 64/2, 121-132. doi: 10.4154/GC.2011.10

KOVAČIĆ, M., ĆORIĆ, S., MARKOVIĆ, F., PEZELJ, Đ., BAKRAČ, K., HAJEK-TADESSE, V., VRSALJKO, D., BOŠNJAK MAKOVEC, M., KAMPIĆ, Š., RITOSSA, A. \& BORTEK, Ž: (2015): Granica srednjeg i gornjeg miocena (sarmat/panon) u Središnjem Paratetisu (lokalitet Vranović, Slavonija) (The Middle/Upper Miocene (Sarmatian/Pannonian) Boundary in Central Paratethys (Vranović locality, Slavonija).- In: HORVAT, M. \& WACHA, L. (eds.): Abstract book. 5th Croatian geological congress with international participation, Osijek 23.-25.09.2015. Croatian Geological Survey, 136-137.

KOVAČIĆ, M., MANDIC, O. \& TOMLJENOVIC, B. (2016): Miocene paleo-lakes of the southwestern Pannonian Basin.- In: MANDIC, O., PAVELIĆ, D., KOVAČIĆ, M., SANT, K., ANDRIC, N. \& HRVATOVIĆ, H. (eds): Field Trip Guidebook. Lake - Basin - Evolution, RCMNS Interim Colloquium 2016 \& Croatian Geological Society Limnogeology Workshop, Zagreb (Croatian Geological Society), 11-31.

KOVAČIĆ, M., MARKOVIĆ, F., ĆORIĆ, S., PEZELJ, Đ., VRSALJKO, D., BAKRAČ, K., HAJEK-TADESSE, V., RITOSSA, A. \& TARNAJ, I. (2017a): Stop 4 Vranović. Disintegration of the Central Paratethys and origin of the Lake Pannon.- In: KOVAČIĆ, M., WACHA, L. \& HORVAT, M. (eds.): Neogene of the Paratethyan region. 7th International Workshop on the Neogene from the Central and SouthEastern Europe. RCMNS Interim Colloquium. Field trip guidebook. Croatian Geological Society, Zagreb, 22-25.

KOVAČIĆ, M., MANDIC, O., HORVAT, M. \& KUREČIĆ, T. (2017b): Stop 6 Petnja. The Termination of Lake Pannon and the Origin of Lake Slavonija.- In: KOVAČIĆ, M., WACHA, L. \& HORVAT, M. (Eds.): Neogene of the Paratethyan region. 7th International Workshop on the Neogene from the Central and South-Eastern Europe. RCMNS Interim Colloquium. Field trip guidebook. Croatian Geological Society, Zagreb, pp. 22-25.

KOVÁCS, Á., BALÁZS, A., ŠPELIĆ, M., SZTANÓ, O. (under review): Forced or normal regression signals in a lacustrine basin? Insights from 3D stratigraphic forward modelling in the SW Pannonian Basin.- Global and Planetary Change.

KROLOPP, E. (2002): Alsó-pleisztocén Mollusca-fauna a Görgeteg-I fúrásból [Lower Pleistocene Mollusc fauna from the Borehole Görgeteg-I (SW Hungary) - in Hungarian].-Földtani Közlöny, 132/1, 89-94.

LUČIĆ, D., SAFTIĆ, B., KRIZMANIĆ, K., PRELOGOVIĆ, E., BRITVIĆ, V., MESIĆ, I. \& TADEJ, J. (2001): The Neogene evolution and hydrocarbon potential of the Pannonian Basin in Croatia.- Marine and Petroleum Geology, 18, 133-147. doi: 10.1016/S0264-8172(00)00038-6

MAGYAR, I. (2004): Tanulságok a hazai pannóniai puhatestü-rétegtan történetéből [What lesson can we learn from the hundred-year history of the Lake Pannon mollusc biostratigraphy in Hungary - in Hungarian].- Földtani Közlöny, 134/3, 369-390.

MAGYAR, I. \& GEARY, D.H. (2012): Biostratigraphy in a Late Neogene Caspian-type lacustrine basin: Lake Pannon, Hungary.- In: BAGANZ, O.V., BARTOV, Y., BOHÁCS, K. \& NUMMEDAL, D. (eds.): Lacustrine sandstone reservoirs and hydrocarbon systems. AAPG Memoir 95, 255-264. doi: 10.1306/13291392M953142

MAGYAR, I. \& SZTANÓ, O. (2008): Is there a Messinian unconformity in the Central Paratethys? - Stratigraphy, 5, 247-257.

MAGYAR, I., GEARY, D.H., SÜTÖ-SZENTAI, M., LANTOS, M. \& MÜLLER, P. (1999): Integrated biostratigraphic, magnetostratigraphic and chronostratigraphic correlations of the Late Miocene Lake Pannon deposits.- Acta Geologica Hungarica, 42, 5-31.

MAGYAR, I., MÜLLER, P., GEARY, D.H., SANDERS, H.C. \& TARI, G.C. (2000): Diachronous deposits of Lake Pannon in the Kisalföld basin reflect basin and mollusc evolution.-Abhandlungen der Geologischen Bundesanstalt, 56, 669-678.

MAGYAR, I., JUHÁSZ, GY., SZUROMI-KORECZ, A. \& SÜTÖ-SZENTAI, M. (2004): A pannóniai Tótkomlósi Mészmárga Tagozat kifejlődése és kora a Battonya-pusztaföldvári-hátság környezetében [The Tótkomlós Calcareous Marl Member of the Lake Pannon sedimentary sequence in the Battonya-Pusztaföldvár region, SE Hungary - in Hungarian]. - Földtani Közlöny, 133, 521-540.

MAGYAR, I., RADIVOJEVIĆ, D., SZTANÓ O., SYNAK, R., UJSZÁSZI, K. \& PÓCSIK, M. (2013): Progradation of the paleo-Danube shelf margin across the Pannonian Basin during the Late Miocene and Early Pliocene.- Global and Planetary Change, 103, 168-173. doi: 10.1016/j.gloplacha.2012.06.007

MAGYAR, I., SZTANÓ, O., SEBE, K., KATONA, T.L., CSOMA, V., GÖRÖG, Á., TÓTH, E., SZUROMI-KORECZ, A., ŠUJAN, M., BRAUCHER R., RUSZKIC-
ZAY-RÜDIGER ZS., KOROKNAI B., WÓRUM G., SANT, K., KELDER, N. \& KRIJGSMAN, W. (2019): Towards a high-resolution chronostratigraphy and geochronology for the Pannonian Stage: Significance of the Paks cores (Central Pannonian Basin).- Földtani Közlöny, 149, 351-370. doi: 10.23928/foldt.kozl.2019.149.4.351

MALVIĆ, T. \& CVETKOVIĆ, M. (2013): Lithostratigraphic units in the Drava Depression (Croatian and Hungarian parts) - a correlation.- Nafta, 64/1, 27-33.

MANDIC, O., KUREČIĆ, T., NEUBAUER, T.A. \& HARZHAUSER, M. (2015): Stratigraphic and palaeogeographic significance of lacustrine molluscs from the Pliocene Viviparus beds in central Croatia.- Geologia Croatica, 68/3, 179-207. doi: 10.4154/ gc. 2015.15

MÜLLER, P. \& MAGYAR, I. (1992): Continuous record of the evolution of lacustrine cardiid bivalves in the late Miocene Pannonian Lake.- Acta Palaeontologica Polonica, 36, 353-372.

MURPHY, A. \& SALVADOR, A. (1999): International Stratigraphic Guide - An abridged version.- Episodes, 22/4, 255-271.

NÁDOR, A. \& SZTANÓ, O. (2011): Lateral and vertical variability of channel belt stacking density as a function of subsidence and sediment supply: field evidence from the intramountaine Körös Basin, Hungary.- SEPM Special Publication, 97, 375 392. doi: 10.2110 /sepmsp.097.375

NAGYMAROSY, A. \& HÁMOR, G. (2012): Genesis and Evolution of the Pannonian Basin. In: HAAS J. (ed.): Geology of Hungary.- Springer, Heidelberg, 149-198. doi: 10.1007/978-3-642-21910-8

PAVELIĆ, D. (2001): Tectonostratigraphic model for the North Croatian and North Bosnian sector of the Miocene Pannonian Basin System.- Basin Research, 12, 359-376. doi: 10.1046/j.0950-091x.2001.00155.x

PAVELIĆ, D. \& KOVAČIĆ, M. (2018): Sedimentology and stratigraphy of the Neogene rift-type North Croatian Basin (Pannonian Basin System, Croatia): A review.- Marine and Petroleum Geology, 91, 455-469. doi: 10.1016/j.marpetgeo.2018.01.026

PAVELIĆ, D., KOVAČIĆ, M., MIKNIĆ, M., AVANIĆ, R., VRSALJKO, D., BAKRAČ, K., TIŠLJAR, J. GALOVIĆ, I. \& BORTEK, Ž. (2003): The Evolution of the Miocene Environments in the Slavonian Mts. Area (Northern Croatia).- In: VLAHOVIĆ, I. \& TIŠLJAR, J. (eds.): Evolution of Depositional Environments from the Paleozoic to the Quaternary in the Karst Dinarides and the Pannonian Basin. Field Trip Guidebook, 22, IAS, 173-181.

PIGOTT, J.D. \& RADIVOJEVIĆ, D. (2010): Seismic Stratigraphy Based Chronostratigraphy (SSBC) of the Serbian Banat Region of the Pannonian Basin.- Central European Journal of Geosciences, 2/4, 481-500. doi: 10.2478/v10085-010-0027-2

PIKIJA, M. (2009): Vapnenačko-klastične naslage (sarmat, panon - M5,6) [Limestone clastic deposits (Sarmatian, Pannonian - M5,6) - in Croatian].- In: VELIĆ, I. \& VLAHOVIĆ, I. (eds.): Tumač Geološke karte Republike Hrvatske 1:300.000 [Explanatory note of the Basic Geological Map of the Republic of Croatia 1:300000 - in Croatian]. Croatian Geological Survey, Zagreb, 141 p.

POGÁCSÁS, GY. \& RÉVÉSZ, I. (1987): Seismic stratigraphic and sedimentological analysis of Neogene delta features in the Pannonian Basin.- Annals of the Geological Institute of Hungary, 70, 267-273.

PRELOGOVIĆ, E., SAFTIĆ, B., KUK, V., VELIĆ, J., DRAGAŠ, M. \& LUČIĆ, D. (1998): Tectonic activity in the Croatian part of the Pannonian basin.- Tectonophysics, 297, 283-293. doi: 10.1016/S0040-1951(98)00173-5

RAKUSZ, GY. \& STRAUSZ, L. (1953): A Villányi-hegység földtana [Geology of the Villány Hills - in Hungarian].-Annals of the Geological Institute of Hungary, 41/2, $27 \mathrm{p}$.

RÖGL, F. (1996): Stratigraphic correlation of the Paratethys Oligocene and Miocene.Mitt. Gesell. Geol. Bergbaustud. Österr., 41, 65-73 .

SACCHI, M., TONIELLI, R., CSERNY, T., DÖVÉNYI, P., HORVÁTH, F., MAGYARI, O., MCGEE, T.M. \& MIRABILE, L. (1998): Seismic stratigraphy of the Late Miocene sequence beneath Lake Balaton, Pannonian basin, Hungary.-Acta Geologica Hungarica, 41, 63-88.

SACCHI, M., HORVÁTH, F. \& MAGYARI, O. (1999): Role of unconformity-bounded units in the stratigraphy of the continental record: a case study from the Late Miocene of the western Pannonian Basin, Hungary.- In: DURAND, B., JOLIVET, L., HORVÁTH, F. \& SÉRANNE, M. (eds.): The Mediterranean basins: Tertiary extension within the Alpine orogen. Geological Society, London, Special Publications, 156, 357-390. doi: 10.1144/GSL.SP.1999.156.01.17

SAFTIĆ, B., VELIĆ, J., SZTANÓ, O., JUHÁSZ, GY. \& IVKOVIĆ, Z. (2003): Tertiary Subsurface Facies, Source Rocks and Hydrocarbon Reservoirs in the SW Part of the Pannonian Basin (Northern Croatia and South-Western Hungary).- Geologia Croatica, 56, 101-122.

SEBE, K., KONRÁD, GY. \& MAGYAR, I. (2013): A legmagasabban fekvő mecseki pannon-tavi üledékek helyzete és kora [On the position and age of the highest-lying Lake Pannon deposits in the Mecsek Mts (SW Hungary) - in Hungarian].- Földtani Közlöny, 143/1, 445-468.

SEBE, K., CSILLAG, G., DULAI, A., GASPARIK, M., MAGYAR, I., SELMECZI, I., SZABÓ, M., SZTANÓ, O. \& SZUROMI-KORECZ, A. (2015): Neogene stratigraphy in the Mecsek region.- In: BARTHA, I-R., KRIVÁN, Á., MAGYAR, I. \& SEBE, K. (eds.): Neogene of the Paratethyan Region. 6th Workshop on the Neogene 
of Central and South-Eastern Europe. An RCMNS Interim Colloquium. Programme, Abstracts, Field Trip Guidebook. 2015.05.31-06.03, Orfü. Hungarian Geological Society, Budapest, 102-124.

SEBE, K., MAGYAR, I., KOVAČIĆ, M., SZTANÓ, O., BOTKA, D., CSOMA, V., SZUROMI-KORECZ, A., KRIZMANIĆ, K. \& KOVÁCS, Á. (2019): Lake Pannon calcareous marls in the SW Pannonian Basin: lithology, stratigraphy and bounding surfaces.- In: TARI G. \& SACHSENHOFER, R. (eds.): Paratethys Petroleum Systems Between Central Europe and the Caspian Region. AAPG, Vienna, P-50.

STEVANOVIĆ, P.M. (1961): Pontische fauna mit Limnocardium petersi bei Kadar an der Save (Nordbosnien).- Annales Géologiques de la Péninsule Balkanique, 28, $177-$ 216.

SÜTÖ-SZENTAI, M. (1982): Organic microplanktonic biozones in the Pannonian complex of Central Transdanubia.- Annual Report of the Hungarian Geological Institute of 1980, 309-344.

SÜTÖ-SZENTAI, M. (1988): Microplankton zones of organic skeleton in the Pannonian s.l. stratum complex and in the upper part of the Sarmatian strata.- Acta Botanica Hungarica, 34/(3-4), 339-360

SÜTÖ-SZENTAI, M. (1990): Mikroplanktonflora der pontischen (oberpannonischen) Bildungen Ungarns.- In: STEVANOVIĆ, P.M., NEVESSKAJA, L.A., MARINESCU, F.L., SOKAĆ, A. \& JÁMBOR Á. (eds.): Chronostratigraphie und Neostratotypen. Neogen der Westlichen (,Zentrale“) Paratethys VIII, Pl1, Pontien. JAZU and SANU, Zagreb-Beograd, 842-869.

SÜTŐ-SZENTAI, M. (1991): Szervesvázú mikroplankton zónák Magyarország pannóniai rétegösszletében. Újabb adatok a zónációról és a dinoflagellaták evolúciójáról [Organic-walled microplankton zones of the Pannonian in Hungary. New data on the zonation and dinoflagellate evolution. - in Hungarian].-Öslénytani Viták / Discussiones Palaeontologicae, 36-37, 157-200.

SÜTŐ-SZENTAI, M. (1994): Microplankton associations of organic skeleton in the surroundings of Villány Mts.- Földtani Közlöny, 124, 451-478.

SÜTÖ-SZENTAI, M. (2000): Organic walled microplankton zonation of the Pannonian s.l. in the surroundings of Kaskantyú, Paks and Tengelic (Hungary).- Annual Report of the Geological Institute of Hungary of 1994-1995, 153-175.

SÜTÖ-SZENTAI, M. (2011): Az Egerág-7 és Bosta-1. számú fúrások pannóniai dinoflagelláta együttesei (Dél-Dunántúl) [Pannonian dinoflagellate associations from boreholes Egerág No. 7 and Bosta No. 1 (Southern Hungary) - in Hungarian].- eActa Naturalia Pannonica, 2, 111-113.

SÜTÖ-SZENTAI, M. \& SZEGÖ, É. (2008): Organic-walled microplankton studies from beds of the Sarmatian-Pannonian stratotype section at Marosorbó (Oarba de Mures), Transylvanian Basin.- Földtani Közlöny, 138, 279-296.

SOLIMAN, A. \& RIDING, J.B. (2017): Late Miocene (Tortonian) gonyaulacacean dinoflagellate cysts from the Vienna Basin, Austria.- Review of Palaeobotany and Palynology, 244, 325-346. doi: 10.1016/j.revpalbo.2017.02.003

SZÓNOKY, M., DOBOS-HORTOBÁGYI, E., GULYÁS, S., SZUROMI-KORECZ, A., MÜLLER, P., GEARY, D.H. \& MAGYAR, I. (1999): Árpád, a classic locality of Lake Pannon bivalves.- Acta Geologica Hungarica, 42/1, 89-108.

SZTANÓ, O. \& MAGYAR, I. (2007): Deltaic Parasequences on Gamma Logs, Ultra-high Resolution Seismic Images and Outcrops of Lake Pannon Deposits.- Joannea Geologie und Paläontologie, 9, 105-108.

SZTANÓ, O., KRÉZSEK, CS., MAGYAR, I., WANEK, F. \& JUHÁSZ, GY. (2005): Sedimentary cycles and rhythms in a Sarmatian to Pannonian (Late Miocene) transitional section at Oarba de Mures/Marosorbó, Transylvanian Basin.- Acta Geologica Hungarica, 48, 235-257.

SZTANÓ, O., MAGYARI, Á. \& TÓTH, P. (2010): Gilbert-típusú delta a pannóniai Kállai Kavics Tapolca környéki elöfordulásaiban [Gilbert-type delta in the Pannonian Kálla Gravel near Tapolca, Hungary - in Hungarian].- Földtani Közlöny, 140/2, $167-182$.

SZTANÓ, O., MAGYAR, I., SZÓNOKY, M., LANTOS, M., MÜLLER, P., LENKEY, L., KATONA, L. \& CSILLAG, G. (2013a): A Tihanyi Formáció a Balaton környékén: típusszelvény, képződési körülmények, rétegtani jellemzés [Tihany Formation in the surroundings of Lake Balaton: type locality, depositional setting and stratigraphy - in Hungarian].- Földtani Közlöny, 143, 73-98.
SZTANÓ, O., SZAFIÁN, P., MAGYAR, I., HORÁNYI, A., BADA, G., HUGHES, D.W., HOYER, D.L. \& WALLIS, R.J. (2013b): Aggradation and progradation controlled clinothems and deep-water sand delivery model in the Neogene Lake Pannon, Makó Trough, Pannonian Basin, SE Hungary.- Global and Planetary Change, 103, 149-167. doi: 10.1016/j.gloplacha.2012.05.026

SZTANÓ, O., SEBE, K., MAGYAR, I. \& CSILLAG, G. (2015): Turbidites as indicators of paleotopography, Late Miocene Lake Pannon, Western Mecsek (Hungary).--Geologica Carpathica, 66/4, 331-344. doi: 10.1515/geoca-2015-0029

SZTANÓ, O., KOVÁČ, M., MAGYAR, I., ŠUJAN, M., FODOR, L., UHRIN, A., RYBÁR, S., CSILLAG, G. \& TŐKÉS, L. (2016): Late Miocene sedimentary record of the Danube / Kisalföld Basin: interregional correlation of depositional systems, stratigraphy and structural evolution.- Geologica Carpathica, 67/6, 525-542. doi: 10.1515/geoca-2016-0033

ŠIKIĆ, K., BASCH, O. \& ŠIMUNIĆ, An. (1979): Osnovna geološka karta SFRJ 1:100000, Tumač za list Zagreb [Basic Geological Map of SFRY 1:100000, Geology of the Zagreb sheet - in Croatian].- Croatian Geological Survey, Department of Geology, Beograd, 1-81.

ŠIMON, J. (1966): Shematski litostratigrafski presjek. Litostratigrafske jedinice tercijara područja Savske potolone, istočnog dijela Dravske potoline i istočne Slavonije [translation in English - in Croatian].- Fond stručne dokumentacije, Služba istraživanja, INA-Naftaplin.

ŠIMON, J. (1980): Prilog stratigrafiji u taložnom sustavu pješčanih rezervoara Sava-grupe naslaga mlađeg tercijara u Panonskom bazenu sjeverne Hrvatske [- in Croatian].Unpubl. PhD. Thesis, University of Zagreb, $66 \mathrm{p}$.

ŠUJAN, M., BRAUCHER, R., TIBENSKÝ, M., FORDINÁL, K., RYBÁR, S., KOVÁČ, M. \& ASTERTEAM (2020): Effects of spatially variable accommodation rate on channel belt distribution in an alluvial sequence: Authigenic 10Be/9Be-based Bayesian age-depth models applied to the upper Miocene Volkovce Fm. (northern Pannonian Basin System, Slovakia).- Sedimentary Geology, 397. doi: 10.1016/j. sedgeo.2019.105566

TOMLJENOVIĆ, B. \& CSONTOS, L. (2001): Neogene-Quaternary structures in the border zone between Alps, Dinarides and Pannonian basin (Hrvatsko zagorje and Karlovac basins, Croatia).- Int. J. Earth Sciences (Geol. Rundschau), 90, 560-578. doi: $10.1007 / \mathrm{s} 005310000176$

TROSKOT-ČORBIĆ, T., VELIĆ, J. \& MALVIĆ, T. (2009): Comparison of the Middle Miocene and the Upper Miocene source rock formations in the Sava Depression (Pannonian Basin, Croatia).- Geologia Croatica, 62/2, 123-133. doi: 10.4154/ GC.2009.11

UHRIN, A., SZTANÓ, O., CSILLAG, G., HÁMORI, Z. (2011): Késő-miocén-pliocén folyók rekonstrukciója a Vértes délkeleti előterében [Reconstruction of Late Miocene - Pliocene rivers in south-eastern foreland of the Vértes Hills - in Hungarian].- Földtani Közlöny, 141/4, 363-381.

UJSZÁSZI, K. \& VAKARCS, G. (1993): Sequence stratigraphic analysis in the south Transdanubian region, Hungary.- Geophysical Transactions, 38, 69-87.

VAN GELDER, I.E., MATENCO, L., WILLINGSHOFER, E., TOMLJENOVIĆ, B., ANDRIESSEN, P.A.M., DUCEA, M.N., BENIEST, A. \& GRUIĆ, A. (2015): The tectonic evolution of a critical segment of the Dinarides-Alps connection: Kinematic and geochronological inferences from the Medvednica Mountains, NE Croatia.Tectonics, 34, 1952-1978, doi: 10.1002/2015TC003937

VASILIEV, I., BAKRAČ, K., KOVAČIĆ, M., ABDUL AZIZ, H. \& KRIJGSMAN, W. (2007): Palaeomagnetic results from the Sarmatian/Pannonian boundary in NorthEastern Croatia (Vranović section, Našice quarry).- Geologia Croatica, 60/2, 151-163.

VELIĆ, J. (2007): Geologija ležišta nafte i plina.- University of Zagreb, 342 p.

VRBANAC, B. (2002): Chronohorizons Based on Resistivity Curve Variations - Upper Miocene Sediments of the Ivanić Grad Formation in the Sava Depression (NW Croatia).- Geologia Croatica, 55/1, 11-23.

VRSALJKO, D. (1999): The Pannonian palaeoecology and biostratigraphy of molluscs from Kostanjek - Medvednica Mt., Croatia.- Geologia Croatica, 52, 9-27.

WIJBRANS, J., NÉMETH, K., MARTIN, U. \& BALOGH, K. (2007): 40Ar/39Ar geochronology of Neogene phreatomagmatic volcanism in the western Pannonian Basin, Hungary.- Journal of Volcanology and Geothermal Research, 164, 193-204. doi: 10.1016/j.jvolgeores.2007.05.009 
Supplement 1. Location of outcrops mentioned in the text.

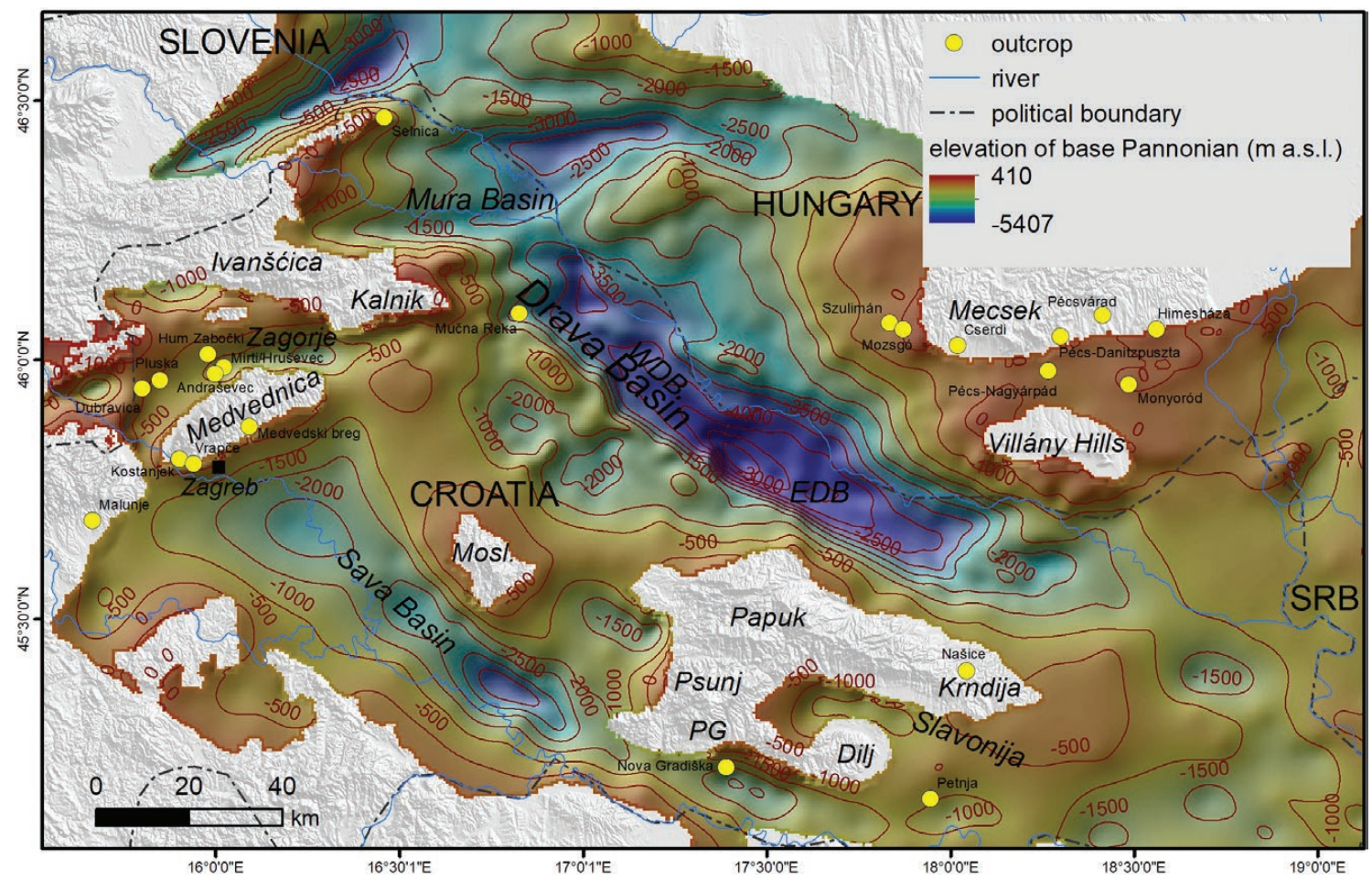

